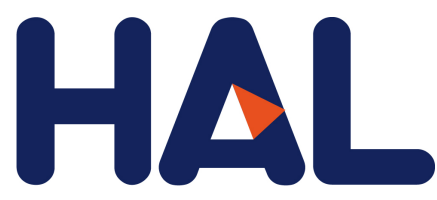

archives-ouvertes

\title{
Resistance of native oak to recurrent drought conditions simulating predicted climatic changes in the Mediterranean region
}

Amélie Saunier, Elena Ormeño, Michel Havaux, Henri Wortham, Brigitte Ksas, Brice Temime-Roussel, James Blande, Caroline Lecareux, Jean-Philippe Mevy, Anne Bousquet-Mélou, et al.

\section{To cite this version:}

Amélie Saunier, Elena Ormeño, Michel Havaux, Henri Wortham, Brigitte Ksas, et al.. Resistance of native oak to recurrent drought conditions simulating predicted climatic changes in the Mediterranean region. Plant Cell

Environment, 2018, 41 (10), pp.2299 - 2312. <10.1111/pce.13331>. <hal-01907454>

\section{HAL Id: hal-01907454 \\ https://hal-amu.archives-ouvertes.fr/hal-01907454}

Submitted on 20 Nov 2018

HAL is a multi-disciplinary open access archive for the deposit and dissemination of scientific research documents, whether they are published or not. The documents may come from teaching and research institutions in France or abroad, or from public or private research centers.
L'archive ouverte pluridisciplinaire HAL, est destinée au dépôt et à la diffusion de documents scientifiques de niveau recherche, publiés ou non, émanant des établissements d'enseignement et de recherche français ou étrangers, des laboratoires publics ou privés. 
Resistance of native oak to recurrent drought conditions simulating predicted climatic changes in the Mediterranean region

\section{Oak forest under several years of drought}

Amélie Saunier ${ }^{1,2^{*}}$, Elena Ormeño ${ }^{1}$, Michel Havaux ${ }^{3}$, Henri Wortham ${ }^{4}$, Brigitte Ksas ${ }^{3}$, Brice Temime-Roussel ${ }^{4}$, James D. Blande ${ }^{2}$, Caroline Lecareux ${ }^{1}$, Jean-Philippe Mévy ${ }^{1}$, Anne Bousquet-Mélou ${ }^{1}$, Thierry Gauquelin ${ }^{1}$, Catherine Fernandez ${ }^{1}$.

${ }^{1}$ Aix Marseille Univ, Univ Avignon, CNRS, IRD, IMBE, Marseille France.

${ }^{2}$ Department of Environmental and Biological Sciences, University of Eastern Finland, P.O. Box 1627, 70211 Kuopio, Finland

${ }^{3}$ CEA Cadarache, CNRS UMR 7265 BVME, Aix-Marseille Univ., Laboratoire d'Ecophysiologie Moléculaire des Plantes, 13108 Saint-Paul-lez-Durance, France ${ }^{4}$ Aix Marseille Univ, CNRS, LCE, Laboratoire de Chimie de l'Environnement, Marseille, France

\section{*Corresponding author}

Amélie Saunier

Department of Environmental and Biological Sciences, University of Eastern Finland,

P.O. Box 1627,

70211 Kuopio, Finland

amelie_saunier@outlook.fr, +33 (0)6 88350436 


\begin{abstract}
The capacity of a Quercus pubescens forest to resist recurrent drought was assessed on an in situ experimental platform through the measurement of a large set of traits (ecophysiological and metabolic) studied under natural drought (ND) and amplified drought induced by partial rain exclusion $(\mathrm{AD})$. This study was performed during the $3^{\text {rd }}$ and $4^{\text {th }}$ years of $\mathrm{AD}$, which correspond to conditions of moderate AD in 2014 and harsher AD in 2015, respectively. Although water potential $(\Psi)$ and net photosynthesis $(P n)$ were noticeably reduced under AD in 2015 compared to ND, trees showed similar growth and no oxidative stress. The absence of oxidative damage could be due to a strong accumulation of $\alpha$-tocopherol, suggesting that this compound is a major component of the $Q$. pubescens antioxidant system. Other antioxidants were rather stable under $\mathrm{AD}$ in 2014, but slight changes started to be observed in 2015 (carotenoids and isoprene) due to harsher conditions. Our results indicate that $Q$. pubescens could be able to cope with $\mathrm{AD}$, for at least 4 years, likely due to its antioxidant system. However, growth decrease was observed during the $5^{\text {th }}$ year (2016) of $\mathrm{AD}$, suggesting that this resistance could be threatened over longer periods of recurrent drought.
\end{abstract}

Keywords: drought, antioxidants, growth, gas exchanges, isoprene emissions 


\section{Introduction}

Mediterranean forests have high resilience to extreme drought episodes (Lloret et al. 2004; Saura-Mas et al. 2015). However, predictions based on recent scenarios in the Mediterranean area show a reduction in annual precipitation of up to $30 \%$ by the end of this century accompanied by longer periods of summer drought stress (i.e. summer drought intensification) compared to current conditions (Giorgi \& Lionello 2008; IPCC 2013; Polade et al. 2014). Thus, climate change could consist of recurrent drought periods, extending over years, and the response of Mediterranean forests to such recurrent stress remains largely unknown (Niinemets 2010; Brzostek et al. 2014).

Water deficit eventually leads to stomatal closure reducing leaf gas exchange, especially carbon uptake. In this way, the photosynthetic processes could be disturbed and reactive oxygen species (ROS) produced due to limited ability to dissipate light energy and the use of the water-water cycle, hence increasing the oxidative pressure inside leaves (Chaves et al. 2009; Ehonen et al. 2017). ROS can lead to cell death through damage to proteins, lipids, carbohydrates and/or DNA (Halliwell 2006; Gill \& Tuteja 2010).

Plants employ several mechanisms to cope with oxidative stress (Blokhina et al. 2003; Jaleel et al. 2009). Production of antioxidant-related defence metabolites prevails as a way to tolerate oxidative stress and, a fortiori, long-lasting and intense drought periods. A large variety of compounds produced by plants are well known for their antioxidant properties. Carotenoids are an important family of ROS scavengers (Edge et al. 1997; Ramel et al. 2012), especially those involved in the xanthophyll cycle (violaxanthin, zeaxanthin, antheraxanthin), which protect the photochemical processes by favouring non-photochemical energy dissipation within the antenna of photosystem II (Demmig-Adams \& Adams 1996; Reddy et al. 2004). The tocochromanols ( $\alpha$-tocopherol and plastochromanol), which are lipid-soluble chloroplastic antioxidants (DellaPenna \& Pogson 2006; Kruk et al. 2014), and ascorbate and 
glutathione, which are water-soluble (Noctor \& Foyer 1998), also have strong antioxidant power. Moreover, plants can also produce enzymatic antioxidants such as catalase, peroxidase, superoxide dismutase or thiol reductases (Ahmad et al. 2010).

Besides these universal antioxidants, plants also produce other types of antioxidants, such as terpenes and phenolic compounds, whose diversity is non-universal or species-specific. Isoprene, the main volatile terpene emitted by plants, seems to maintain the membrane stability of thylakoids preserving the photosynthetic machinery under oxidative conditions (Affek \& Yakir 2002, Velikova et al. 2011). Moreover, phenolic compounds, especially phenolic acids, flavonoids and tannins, feature a strong capacity to quench ROS (Close \& McArthur 2002). As a result, both terpenes (including isoprene) and phenolic compounds are expected to be increasingly produced in response to abiotic oxidative pressures, which is in accordance with the unified mechanism of action for volatile terpenes (Vickers et al. 2009) and the oxidative pressure theory for phenolic compounds (Close et al. 2004).

Several studies reviewed in Munné-Bosch (2005) provide evidence that plant protection against oxidative stresses is not due to a single compound, but to the whole bouquet of antioxidants. They also show that compensatory mechanisms can occur between antioxidants as well as between antioxidants and growth. Antioxidant synthesis requires carbon allocation, but this allocation could be limited under intense drought since photosynthetically assimilated carbon is limited (Chaves et al. 2003). This trade-off or compensation is, however, not necessarily observed since primary reserves of plant carbohydrates (starch for instance) can be mobilized to support metabolite production (Brilli et al. 2007; Chaves et al. 2009). Numerous studies have already focused on gas exchange and/or growth and/or antioxidant concentration or emission under several drought treatments, mostly applied under controlled conditions, and more rarely under natural conditions (Llusià \& Peñuelas 1998; Jiang \& Zhang 2002; Hernández et al. 2004). However, there is still a lack of knowledge on how plants resist 
in situ amplified recurrent drought (several years), especially in the Mediterranean area where plants often encounter this type of stress.

Quercus pubescens Willd, our vegetal model, is one of the most widespread species in the Northern part of the Mediterranean basin. This species is a thermophilic and xerophilic species, highly resistant to drought conditions. This study aimed to evaluate if $Q$. pubescens forest can resist the recurrent and amplified drought expected with climate change in the Mediterranean region. We addressed the aim by measuring a vast array of ecophysiological (pre-dawn and midday water potential, stomatal conductance to water, net photosynthesis, chlorophyll content, chlorophyll fluorescence and lipid peroxidation as a direct proxy of cell oxidation) and metabolic (non-universal and universal antioxidants) traits. We hypothesized that (i) recurrent amplified drought (AD) could increase the oxidative pressure in leaves, leading to modifications of the antioxidant system, and (ii) carbon assimilation decrease with recurrent $\mathrm{AD}$ would involve trade-offs or compensations between antioxidants or between antioxidants and growth.

\section{Materials and Methods}

\section{Experimental site}

The study was performed at the Oak Observatory at the "Observatoire de Haute Provence $\left(\mathrm{O}_{3} \mathrm{HP}\right)$ ", located $60 \mathrm{~km}$ North of Marseille ( $\left.5^{\circ} 42^{\prime} 44^{\prime \prime} \mathrm{E}, 43^{\circ} 55^{\prime} 54^{\prime \prime} \mathrm{N}\right)$, at an elevation of 650 $\mathrm{m}$ above sea level. The $\mathrm{O}_{3} \mathrm{HP}\left(955 \mathrm{~m}^{2}\right)$, free from human disturbance for more than 70 years, consists of a homogeneous forest mainly composed of $Q$. pubescens, aged 70 years-old. This forest site features a supra-Mediterranean sub-humid bioclimate with an average annual precipitation of $830 \mathrm{~mm}$, averaged from 1967 to 2000 (Santonja et al. 2015). Hence, this is considered a site with a Mediterranean climate, but with the peculiarity that the dry period naturally takes place for just one or two months per year. Using a rainfall exclusion device 
mechanically deployed to exclude some rain events (Fig. 1), it was possible to reduce natural annual rain by $\sim 30 \%$ over part of the $\mathrm{O}_{3} \mathrm{HP}$ canopy, hereafter referred to as "the amplified drought plot" (AD). This method allowed us to extend the drought period, in an attempt to mimic the current climatic model projections for the end of this century (Giorgi \& Lionello 2008; IPCC 2013; Polade et al. 2014). Two plots were present in the site: a plot $\left(300 \mathrm{~m}^{2}\right)$ subjected to amplified drought $(\mathrm{AD})$ and an adjacent plot $\left(232 \mathrm{~m}^{2}\right)$, which received natural precipitation where trees were subjected to natural drought (ND). Amplified drought started in April 2012 and continued each year from then, principally during the growth period, with a $35 \%$ exclusion of precipitation in 2012 (from April $29^{\text {th }}$ to October $27^{\text {th }}$ ), $33 \%$ in 2013 (from July $7^{\text {th }}$ to December $29^{\text {th }}$ ), $35.5 \%$ in 2014 (from April $8^{\text {th }}$ to December $8^{\text {th }}$ ) and $33.9 \%$ in 2015 (from April $16^{\text {th }}$ to November $21^{\text {st }}$ ). Ombrothermic diagrams - built up using values of precipitation and temperature measured through rain gauges and temperature sensors placed in both plots - indicate that the drought period in the AD plot was extended for 2 months in 2012, 4 months in 2013, and 3 months in 2014 and 2015 compared to the ND plot (Fig. 2).

Moreover, in 2014, $1167 \mathrm{~mm}$ of cumulative precipitation was recorded under ND and 753 mm under AD whereas, in 2015, precipitation dropped to $598 \mathrm{~mm}$ in the ND plot and $395 \mathrm{~mm}$ in the AD plot (Fig. 3) indicating that, in our experiment, 2014 was a wet year whereas 2015 was considered a dry year.

Six measurement campaigns were performed during this study, three in 2014 and three in 2015 , corresponding to the $3^{\text {rd }}$ and $4^{\text {th }}$ year of AD. For each year, one measurement campaign was performed in spring (May $9^{\text {th }}-18^{\text {th }} 2014$ and May $15^{\text {th }}-29^{\text {th }} 2015$ ), summer (July $11^{\text {th }}-19^{\text {th }}$ 2014 and July $18^{\text {th }}-28^{\text {th }} 2015$ ) and autumn (September $30^{\text {th }}$-October $6^{\text {th }} 2014$ and September $\left.18^{\text {th }}-30^{\text {th }} 2015\right)$. The sampling was performed at the branch scale at the top of the canopy on the same five trees per plot throughout the 6 measurement periods (position of the trees can be found in Fig. 1) and two additional trees per plot were included for antioxidant analyses 
(tocochromanols, chlorophylls and carotenoids). Trees were chosen randomly in the heart of each plot (to avoid the buffer zone of $2 \mathrm{~m}$ at the verges of the AD plot) while having canopies accessible from the footbridge.

\section{Ecophysiological traits}

$\mathrm{CO}_{2}$ and $\mathrm{H}_{2} \mathrm{O}$ exchange

Two identical dynamic branch enclosures were used for sampling $\mathrm{CO}_{2}$ and $\mathrm{H}_{2} \mathrm{O}$ exchange as well as isoprene emission (see below). The enclosures are fully described in Genard-Zielinski et al. (2015) and only slight modifications were made as described in Saunier et al. (2017).

Branches used for gas exchange sampling were located at the top of the canopy and exposed to the sun. Each branch was enclosed for 2 days in a $\approx 30$ L PTFE (polytetrafluoroethylene) frame closed with a $50 \mu \mathrm{m}$ thick PTFE film. Branch enclosures were installed on the day before the first measurement and were immediately flushed with a continuous flow of purified air at 9 L.min ${ }^{-1}$ (allowing complete air renewal every 3.33 min) using a PTFE pump (N840.1.2FT.18, KNF, Germany). A PTFE fan was used to ensure a rapid mixing of the chamber air and a slight positive pressure within the enclosure enabled it to be held away from the leaves to avoid biomass damage. Exchange of $\mathrm{CO}_{2}$ and $\mathrm{H}_{2} \mathrm{O}$ of the enclosed branches were continuously measured (every minute) using infrared gas analyzers (IRGA 840A®, LI-COR, USA) at $0.2 \mathrm{~L} \cdot \mathrm{min}^{-1}$. Net photosynthesis $\left(P n, \mu \mathrm{molCO}_{2} \mathrm{~m}^{-2} \mathrm{~s}^{-1}\right)$, stomatal conductance to water $\left(G w, \mathrm{mmolH}_{2} \mathrm{O} \mathrm{m} \mathrm{m}^{-2} \mathrm{~s}^{-1}\right)$ and transpiration rate $\left(E, \mathrm{mmolH}_{2} \mathrm{O} \mathrm{m} \mathrm{m}^{-2} \mathrm{~s}^{-1}\right)$ were calculated using equations described by Von Caemmerer and Farquhar (1981) as presented in Genard-Zielinski et al. (2015). Transpiration rate data are not presented in this work, but were used to calculate the water use efficiency $\left(W U E, \mathrm{mmolCO}_{2} \cdot \mathrm{molH}_{2} \mathrm{O}^{-1}\right.$ ) as $P n / E$. All gas exchange data were averaged between 12:00 and 15:00 (local time). 
Relative humidity (RH) and temperature (T) were measured using an RHT probe (HMP60, Vaisala, Finland) placed inside the chamber and photosynthetically active radiation (PAR) was measured using a quantum sensor (PAR-SA 190®, LI-COR, USA) placed outside the chamber. Measurements with the RHT probe and the PAR sensor were recorded every minute using a data acquisition system (data logger, Li-1400-04®, LI-COR, USA). Once $\mathrm{CO}_{2}$ and $\mathrm{H}_{2} \mathrm{O}$ exchange had been measured, leaves from enclosed branches were collected in order to calculate the surface area of each leaf with a leaf area meter (AM350, ADC Bioscientific Ltd., UK) and to report gas exchange of the whole branch leaf surface. The foliage used for the water potential and biochemical analyses was taken from branches adjacent to those enclosed and used for the gas exchange measurements.

\section{Stem water potential}

Stem water potential at predawn $\left(\Psi_{p d}\right)$ and midday $\left(\Psi_{m}\right)$ were measured from detached stems during each field campaign (except $\Psi_{p d}$ in spring 2014 and $\Psi_{m}$ in autumn 2014) with a Scholander pressure chamber (PMS instrument Co., USA, range 0 - 7Mpa). Two measurements of $\Psi$ were performed on each tree if the difference between both values did not exceed 0.3 MPa. Otherwise, a third measurement was performed.

\section{Chlorophyll fluorescence}

Chlorophyll fluorescence of photosystem II was measured through the maximum quantum efficiency of PS II ( $F v / F m$, the ratio of variable to maximum fluorescence). Measurements were performed on the adaxial side of the leaves, with the leaves dark-adapted for at least 30 min, using a portable fluorimeter (FMS2, Hansatech, UK).

\section{Chlorophyll pigment}


For all biochemical analyses (i.e. including the metabolic traits studied, see below), leaf samples were frozen in liquid nitrogen and stored at $-80^{\circ} \mathrm{C}$ before measurements. Chlorophyll pigments were extracted from leaves in methanol, quantified by HPLC using authentic standards of chlorophyll $a$ and $b$ (Sigma-Aldrich, USA) and expressed in mg.g $\mathrm{DM}^{-1}$, as described by Havaux et al. (2007). The ratio between chlorophyll $a$ and $b$ (Chl $a / C h l b)$ was also calculated as an indicator of PSII antenna size and PS stoichiometry.

\section{Estimation of leaf oxidation through lipid peroxidation imaging}

Lipid peroxidation was visualized in detached leaves by autoluminescence imaging to assess leaf oxidation due to water stress (Havaux et al. 2006). As detailed in Birtic et al. (2011), this technique is based on the measurement of the weak luminescence associated with the slow decomposition of lipid peroxides using a very sensitive photon-imaging system. The intensity of the luminescence signal is proportional to the amount of lipid peroxides present in leaves. In order to validate the applicability of this method on Downy oak, detached leaves were exposed to a photooxidative stress treatment by combining high PAR $\left(1500 \mu \mathrm{mol} \mathrm{m}^{-2} \mathrm{~s}^{-1}\right)$ and low temperature $\left(14^{\circ} \mathrm{C}\right)$. Spontaneous photon emission from detached Downy oak leaves was measured after $3 \mathrm{~h}$ of dark adaptation using a liquid $\mathrm{N}_{2}$ cooled charge-coupled device (CCD) camera. Acquisition time was 20 min and pixel binning was 2 x 2 . The luminescence signals were analyzed and quantified with Image J software.

\section{Growth assessment}

Growth was estimated in ND and AD plots through 3 parameters: i) litter production (g.m $\left.\mathrm{m}^{-2}\right)$ as a direct proxy of leaf biomass production, ii) increase of tree trunk diameter at breast height $\left(\mathrm{DBH}, \mathrm{cm} \cdot \mathrm{yr}^{-1}\right)$ and iii) leaf mass per unit of leaf area (LMA, g.m ${ }^{-2}$ ) indicator of foliage thickness (Vile et al. 2005). Litter production was measured within 8 litter traps $\left(0.24 \mathrm{~m}^{2}\right)$ 
placed on the soil of both plots in 2014 and 2015. Litter traps allowed the collection of senescent leaves during leaf abscission from October to April and thus estimation of the leaf biomass production in each plot. The DBH increase was measured as the difference between DBH in 2016 ( $5^{\text {th }}$ year of AD) and DBH in 2015 (4 $4^{\text {th }}$ year of AD), DBH being always measured at the end of the vegetative period (in December). Note that DBH is the only parameter monitored in 2016. These measurements were performed on all trees of each plot ( $n=146$ in ND and $n=52$ in AD) with a meter (tape measure). Finally, the LMA of enclosed leaves was measured as the ratio between the dry leaf biomass and weight, expressed in $\mathrm{g} \cdot \mathrm{m}^{-2}$. LMA is only presented for autumn 2014 and 2015 for trees followed for gas exchange. We assumed that it was a representative measurement for the whole year as $Q$. pubescens is a winter-deciduous species.

\section{Metabolic traits}

For all metabolic traits studied, leaf samples were collected and immediately frozen in liquid nitrogen and stored at $-80^{\circ} \mathrm{C}$ in a laboratory freezer before extractions.

\section{Tocochromanols}

The $\alpha$-tocopherol and plastochromanol concentrations (ng. $\mathrm{mg}_{\mathrm{DM}}{ }^{-1}$ ) were extracted using the method described by Ksas et al. (2015), which was adapted from Kruk and Karpinski (2006). $\alpha$-tocopherol standards were obtained from (Sigma Aldrich, USA) and the plastochromanol standard was a kind gift from Dr. J. Kruk (Jagiellonian University, Krakow, Poland).

\section{Carotenoid pigments}

Antioxidant carotenoid pigments from the xanthophyll cycle (violaxanthin+antheraxanthin+ zeaxanthin), as well as neoxanthin, lutein and $\beta$-carotene were extracted and analyzed using 
the same method used for chlorophylls (see above, Havaux et al. 2007). Their concentrations (ng. $\mathrm{mg}_{\mathrm{DM}}{ }^{-1}$ ) were calculated from calibration curves performed using pigment standards (Extrasynthèse, France).

\section{Isoprene}

A commercial PTR-ToF-MS 8000 instrument (Ionicon Analytik GmbH, Austria) was used for online measurements of isoprene emissions (Tholl et al. 2006; Jordan et al. 2009) in the enclosure chambers (measurements performed in parallel to gas exchange measurements). A detailed description of the instrument and sampling set up have been previously published (Saunier et al. 2017). Isoprene mixing ratios were calculated based on the signal intensity at $\mathrm{m} / \mathrm{z} 41.038$ and 69.069 using at proton transfer rate constant of $1.9510^{-9} \mathrm{~cm}^{3} \mathrm{~s}^{-1}$ as reported by Cappellin et al. (2012). Isoprene emissions rates (ERiso) between 12:00 and 15:00 (local time), when emissions were the strongest, were calculated by considering the concentrations at the inlet and outlet of the PTFE chamber using the following equation:

where ERiso is expressed in $\mu \mathrm{gC} \mathrm{g}_{\mathrm{DM}}{ }^{-1} \mathrm{~h}^{-1}, \mathrm{Q}_{0}$ is the flow rate of the air introduced into the chamber $\left(\mathrm{L} \mathrm{h}^{-1}\right), \mathrm{C}_{\text {out }}$ and $\mathrm{C}_{\text {in }}$ are the isoprene concentrations in the outflowing and inflowing air respectively $\left(\mu \mathrm{gC} \mathrm{L}^{-1}\right)$ and $\mathrm{B}$ is the total dry biomass matter $\left(\mathrm{g}_{\mathrm{DM}}\right)$. ERiso are not available for autumn 2014 due to a technical problem. Investment of carbon sequestration into isoprene $\left(\mathrm{C}_{\text {iso }}\right)$ was calculated with the following formula:

where ERiso and Pn used in this equation were expressed in $\mu \mathrm{gC} \mathrm{m}^{-2} \mathrm{~h}^{-1}$.

\section{Total phenolic compound index}


Total phenolic compounds index, were extracted using $0.25 \mathrm{~g}_{\mathrm{DM}}$ of lyophilized ground leaves in $20 \mathrm{~mL}$ of methanol:water solvent (70:30). The mixture was shaken constantly for $1 \mathrm{~h}$ at ambient temperature and the extract was then filtered through a membrane with a $0.22 \mu \mathrm{m}$ pore size. The total amount of water-soluble phenolic compounds was determined based on the Folin-Ciocalteu method used by Santonja et al. (2015). The quantitative values were expressed in mg equivalents of gallic acid per g of leaf dry mass.

\section{Starch}

Starch was extracted from $0.1 \mathrm{~g}_{\mathrm{DM}}$ of lyophilized ground leaves in $100 \mu \mathrm{L}$ of ethanol/water solvent (80:20). After addition of $3 \mathrm{~mL}$ of amylase, each sample was incubated in boiling water for 6 min and $100 \mu \mathrm{L}$ of amyloglucosidase was then added. The samples were mixed and incubated for $30 \mathrm{~min}$ at $50{ }^{\circ} \mathrm{C}$ and then transferred into graduated $25 \mathrm{~mL}$ vials. Volumes were adjusted up to $25 \mathrm{~mL}$ with distilled water. An aliquot was centrifuged at $3000 \mathrm{rpm}$ for 10 min. Then, $50 \mu \mathrm{L}$ of each sample was mixed with $2 \mathrm{~mL}$ of distilled water, $100 \mu \mathrm{L}$ of buffer solution and $100 \mu \mathrm{L}$ of $\mathrm{NADP}^{+}$solution. After $3 \mathrm{~min}$, the extract was measured at $340 \mathrm{~nm}$ on a Biomate 3 spectrophotometer (ThermoFisher, USA). A calibration curve was made with a D-glucose solution provided with the analytical kit (Megazyme, USA).

\section{Statistical analyses}

Statistical analyses were performed with STATGRAPHICS® centurion XV (Statpoint Technologies, USA) and R (3.3.2). To evaluate differences between the factors "drought treatments" and "seasons" on every plant trait, we separated the data set in 2014 and 2015, and performed a two-way repeated measures ANOVA followed by Tukey post hoc tests after having checked the normality and homoscedasticity of the data set. Since significant interactions between drought and seasonality occurred, we performed a one-way repeated 
ANOVA followed by Tukey post hoc tests to evaluate the effect of season on ND and AD separately, and Student tests to evaluate differences between ND and AD during each season. Student's tests were also performed to test for differences between both years. Student tests allowed the analysis of differences in growth between AD and ND. In order to check for the occurrence of compensatory mechanisms (increasing the production or emission of some antioxidants as others decrease), Spearman correlations were performed between antioxidants. Spearman correlations were also used to assess the relationship between antioxidants and physiological parameters $\left(P n\right.$ and $\left.\Psi_{p d}\right)$. Correlations were always carried out for each season with years and treatments pooled together.

Principal component analyses (PCA) were performed on antioxidant data for each season, (previously centered and standardized) in order to highlight whether some compounds were produced more under AD in 2014 and 2015 (ade4 package in R) followed by two-way PERMANOVA to check for significance of the results (vegan package in R).

\section{Results}

\section{Water stress level indicators}

Amplified drought had a strong effect on $\Psi_{p d}$ with decreases of 22 and $29 \%$ in summer and autumn of 2014, respectively, and 12 and $43 \%$ in summer and autumn of 2015, respectively (Table 1). $\Psi_{p d}$ in 2014 was higher than in 2015: in summer $2014, \Psi_{p d}$ dropped to -0.70 and 0.90 MPa in ND and AD, respectively, whereas in summer $2015, \Psi_{p d}$ reached -2.41 and -2.74 $\mathrm{MPa}$ in ND and $\mathrm{AD}$, respectively. Differences in $\Psi$ between $\mathrm{AD}$ and ND only occurred in terms of $\Psi_{p d}$ (i.e. no differences in terms of $\left.\Psi_{m}\right)$, except for a drop (-21\%) in $\Psi_{m}$ under AD in autumn 2015. Gw was clearly reduced by AD, which was especially clear in 2015 ( -95\% in summer and autumn) compared to 2014 (from -39 to -56\%). The pattern observed for $P n$ was the same as for $G w$ with a stronger limitation under AD in $2015(-61 \%$ and $-85 \%$ in summer 
and autumn) compared to 2014 ( -33\% over the year). In spring, $P n$ did not show any modification under AD irrespective of the year. WUE only increased under AD in spring 2014 and summer 2015.

Total Chl and Chl a/Chl $b$ ratio only showed a significant drop under AD in 2015, with the effect especially noticeable in autumn with a decrease of $15 \%$. Increase of the ratio was due to an increase of $C h l a$ in spring whereas it was due to a decrease in $C h l b$ in autumn. No change was observed in terms of $F v / F m$ when trees grew under AD, either in 2014 or 2015. Likewise, starch content did not change with drought treatment, irrespective of the year.

Autoluminescence imaging was used to detect lipid peroxidation in $Q$. pubescens leaves. Under photooxidative stress conditions, a high leaf autoluminescence was found for all leaves. This indicates, as expected, strong lipid oxidation, and confirms the applicability of the method for this species (Fig. 4, HL). In both 2014 and 2015, leaf autoluminescence was very low throughout the year and did not increase with AD.

\section{Growth}

Neither leaf biomass production, nor LMA varied between ND and AD in any year tested (Table 2). However, trunk growth, estimated by the DBH increase between 2015 and 2016, was reduced by $43 \%$ under AD compared to ND.

\section{Antioxidants}

Sensitivity to amplified drought and seasonal course

Leaf $\alpha$-tocopherol concentration was not sensitive to AD, irrespective of the season or the year (Fig. 5a and 5b). However, $\alpha$-tocopherol was sensitive to seasonal changes with a marked accumulation of $\alpha$-tocopherol through the seasonal cycle, with minimal, intermediate and maximal concentrations in spring, summer and autumn, respectively, especially in 2015 . 
Likewise, plastochromanol concentrations accumulated from spring to autumn in both 2014 and 2015, and were not affected by AD in 2015 (Fig. 5c and 5d). However, plastochromanol concentrations increased under $\mathrm{AD}$ in 2014, whereas increases were not observed for any of the other antioxidants analyzed.

The concentration of lutein, the major carotenoid in leaves, decreased significantly both under severe AD conditions in 2015 (-24\% and $-18 \%$ in summer and autumn, respectively; Fig. 6a and 6b) and throughout the year (spring > summer > autumn) in 2014 and 2015, contrasting with the trend for tocochromanols. $\beta$-carotene content followed the same pattern as lutein in 2015 with decreases under AD (-14\% and $-22 \%$ in summer and autumn, respectively; Fig. 6c and $6 \mathrm{~d}$ ) and a drop in concentration over the year. The seasonal pattern of $\beta$-carotene in 2014 consisted of a maximal content in summer. Neoxanthin concentration did not vary under AD in 2014, but was also markedly reduced under AD in summer 2015 (Fig. 6e and 6f). Neoxanthin content showed the same seasonal changes as $\beta$-carotene in both years.

Content of the xanthophyll cycle carotenoids (violaxanthin, antheraxanthin and zeaxanthin) was not affected by precipitation restrictions either in 2014 or 2015, except for in autumn 2015 when there was a decrease of $20 \%$. These antioxidants followed a seasonal cycle with a decrease throughout the year during both years, as described for the other carotenoid antioxidants in 2015. Because their response to drought treatment and seasonality was the same and they were issued from the same biochemical cycle, the whole concentration of violaxanthin+antheraxanthin+zeaxanthin is shown throughout the paper.

Isoprene was down-regulated antioxidant since 2014 under AD (Fig. 7) with a decrease in emissions of 50\% and 35\% in spring and summer 2014, respectively. In 2015, when drought was especially intense, isoprene emissions remained low under AD (especially in autumn with $-61 \%$ compared to trees in the ND plot). We also noted that trees growing in the ND plot showed similar isoprene emission rates during the summers of both years $(115.2 \pm 17.9$ and 
124.3 $\pm 17.9 \mu \mathrm{g} \mathrm{C} \mathrm{g}_{\mathrm{DM}}{ }^{-1} \mathrm{~h}^{-1}$ in 2015 and 2014, respectively) while larger emissions were observed in spring 2015 relative to $2014\left(42.5 \pm 12.0\right.$ and $\left.20.3 \pm 3.8 \mu \mathrm{gC} \mathrm{g}_{\mathrm{DM}}{ }^{-1} \mathrm{~h}^{-1}\right)$. The same pattern was observed in the AD plot with higher emissions in spring 2015 compared to 2014 $\left(40.3 \pm 9.2\right.$ and $\left.10.2 \pm 2.3 \mu \mathrm{gC} \mathrm{g}_{\mathrm{DM}}{ }^{-1} \mathrm{~h}^{-1}\right)$. With regard to seasonality, we observed the same pattern during both years with the strongest emission rates recorded in summer compared to the other seasons. Carbon assimilated through $P n$ was clearly more invested into isoprene during the summer compared to the other seasons. This investment (similar between AD and ND) was especially clear in summer 2015 when $\sim 15 \%$ of the fixed $\mathrm{CO}_{2}$ was re-emitted as isoprene compared to about $3 \%$ in 2014 (Fig S1, in supplementary file).

Phenolic compounds index was not sensitive to AD either in 2014 or 2015 (Fig. 8). Moreover, these compounds did not exhibit a seasonal course, irrespective of the year, with similar concentrations during both years.

\section{Main antioxidants vary according to the season and the year}

Antioxidant concentrations mostly remained similar under both drought treatments (Fig. 9a, b, c, PCA, followed by two ways PERMANOVA), except in summer when AD had a marginal effect. By contrast, antioxidant concentrations were strongly dependent on the year and season: $i$ ) in spring, $\beta$-carotene and, to a lesser extent, isoprene and $\alpha$-tocopherol were produced in greater amounts in 2015 compared to 2014; ii) in summer, $\alpha$-tocopherol, plastochromanol and carotenoids belonging to the xanthophyll cycle were produced in greater amounts in 2015. Isoprene and phenolic compounds did not have a high impact on the data repartition for the summer season; iii) in autumn, the xanthophyll cycle carotenoids, $\alpha$ tocopherol and isoprene were produced in greater amounts in 2015 than 2014. Similar to the data for the summer, data repartition in autumn was not highly affected by phenolic compounds. 


\section{Compensatory mechanisms}

Spearman's correlations between antioxidants and physiological parameters $\left(P n\right.$ and $\left.\Psi_{p d}\right)$ showed that, in spring, xanthophyll cycle antioxidants were positively correlated with $P n$ (Table 3 and Tables S1 a and b in supplementary files). In summer, the xanthophyll cycle antioxidants, as well as $\alpha$-tocopherol, were strongly and positively correlated with the drop in water availability (indicated by $\Psi_{p d}$ ), involving a decrease in carbon assimilation. Moreover, the drop in water availability was also associated with a decrease in carotenoids ( $\beta$-carotene and neoxanthin), as indicated by their negative correlation. In autumn, just like in summer, $\alpha-$ tocopherol and xanthophyll cycle antioxidants were positively correlated with the decrease of $\Psi_{p d}$, which was negatively correlated with neoxanthin.

In each season, the three carotenoids, lutein, $\beta$-carotene and neoxanthin, were positively correlated: $i$ ) in spring, only positive correlations were observed between antioxidants, with isoprene positively correlated with neoxanthin and $\beta$-carotene positively correlated with $\alpha$ tocopherol; ii) in summer, $\alpha$-tocopherol was negatively correlated with carotenoids (lutein, $\beta$ carotene and neoxanthin) and positively correlated with the xanthophyll cycle. Plastochromanol was also positively correlated with the xanthophyll cycle; iii) in autumn, $\alpha-$ tocopherol was negatively correlated with neoxanthin and the latter was also negatively correlated with isoprene emissions and xanthophyll cycle pigments. Moreover, isoprene, xanthophyll cycle antioxidants and $\alpha$-tocopherol were positively correlated with each other.

Negative correlations are probably indicators of trade-offs or compensations between antioxidants, whereas positive correlations could reflect synergistic actions of antioxidants.

\section{Discussion}

Amplified drought affects gas exchange by $Q$. pubescens leaves. 
Under mild water deficit in 2014 ( $\Psi_{p d}$ close to - $1.0 \mathrm{MPa}$ in summer AD), Q. pubescens exhibited partial stomatal closure (50\% lower under AD than ND in summer). Although this response resulted in a $40 \%$ decrease of $P n$, it had the advantage of avoiding $\Psi_{m}$ drop under AD (conservative strategy). This response reflects a drought-resistance strategy through drought-avoidance (Martínez-Ferri et al. 2000). However, it also suggests that $Q$. pubescens showed some degree of drought tolerance since, despite the substantial $P n$ decline, $P n$ values were still rather high $\left(\sim 9 \mathrm{molCO}_{2} \mathrm{~m}^{-2} \mathrm{~s}^{-1}\right.$ in summer) (Damesin and Rambal 1995) during this relatively wet year. It should be noted that $Q$. pubescens exhibits other drought-avoidance traits, including a well-known high stem hydraulic efficiency, which is also partly responsible for leaf water maintenance (Nardini \& Pitt 1999; Poyatos et al. 2008; Genard-Zielinski et al. 2014).

In 2015, when harsher drought conditions occurred (up to $\Psi_{p d}$ - $3 \mathrm{MPa}$ in summer under $\mathrm{AD}$ ), Q. pubescens closed its stomata under AD during most of the year (except in spring), which implied a marked limitation of $P n$. This strategy seemed, however, more efficient in summer than in autumn since stomatal closure under $\mathrm{AD}$ in summer prevented $\Psi_{m}$ from dropping compared to ND (drought-avoidance), while in autumn, stomatal closure implied limited $P n$, but could not prevent $\Psi_{m}$ decline, showing the limits of $Q$. pubescens resistance to drought.

Our study indicates that $Q$. pubescens features high plasticity when faced with water scarcity, with a shift from combined drought-avoidance and -tolerance responses under mild water deficit (2014) to a drought-avoidance strategy under more severe dryness (2015). This shift between drought-resistance strategies with respect to gas exchange seems to be common in Mediterranean species (Chaves et al. 2009).

It is important to note that the net photosynthesis decrease observed in 2015 is likely to be due to the harsher climatic conditions of that year, but could also be due to the cumulative effect of recurrent amplified drought as expected with climate change (Brzostek et al. 2014). These 
results suggest that, besides the drought severity of the year, drought recurrence is also a major factor to take into account when evaluating species resistance to expected climate change.

\section{The antioxidant system preserves $Q$. pubescens leaves from drought-induced oxidative}

\section{damage}

The low levels of lipid peroxidation observed in this study (indicator of $Q$. pubescens resistance to water stress) implies that leaves were able to avoid cellular oxidative damage during drought stress, presumably due to several metabolic adjustments and compensations. In 2015, $\mathrm{AD}$ brought about a decrease in lutein, neoxanthin and $\beta$-carotene compared to ND, which is concomitant with the $\Psi_{p d}$ drop. This decrease could be due to the oxidative pressure occurring within leaves resulting in carotenoid oxidation, as demonstrated by Ramel et al. (2012). It is possible that this phenomenon was not efficient enough to protect chloroplasts from oxidative damage since a compensatory mechanism between carotenoids and $\alpha$ tocopherol (negative correlation) was highlighted. This loss of carotenoids, together with an increase in chla/chlb, could also come from reduction of the PSII antenna in AD-treated leaves, since both lutein and neoxanthin are components of the light-harvesting antenna of the photosystems, with neoxanthin being specific to the PSII antenna (Croce et al. 1999). This phenomenon is a typical response of plants to excess light energy (Park II et al. 1997; Ballottari et al. 2007). However, the maximal quantum efficiency of PSII $(F v / F m)$ was not affected by $\mathrm{AD}$, indicating that there was no photoinhibition and that PSII was still functional despite the loss of pigments (Krause \& Weis 1991). Thus, the carotenoid changes could actually reflect an acclimation to light and drought in 2015 and their role as antioxidants through oxidation reactions. 
A striking observation was that lipid-soluble antioxidants ( $\alpha$-tocopherol, plastochromanol) displayed a very strong accumulation in $Q$. pubescens leaves throughout the year, both in 2014 and 2015. Compared to spring, $\alpha$-tocopherol and plastochromanol contents were increased in autumn by a factor of around 8 . Both tocopherol and plastochromanol are known to be located in the chloroplasts (Kruk et al. 2016) and are dependent on light, with an excess of light energy boosting their synthesis (Ksas et al. 2015). The strong accumulation of those compounds in $Q$. pubescens leaves in summer and autumn suggests that trees perceived cellular oxidative stress and responded by inducing synthesis of lipid-soluble antioxidative molecules to protect their chloroplast membranes. Thus, lipid-soluble antioxidative molecules, especially $\alpha$-tocopherol, appeared to play a key role in resilience of the Downy oak forest under recurrent drought.

It was, however, surprising that the accumulation of tocochromanols was similar between ND and $\mathrm{AD}$, although significant perturbations of the photosynthetic apparatus were observed in 2015 under the AD compared to ND. Even though there were no differences between ND and $\mathrm{AD}, \alpha$-tocopherol contents increased with the $\Psi_{p d}$ drop as well as with the decrease of carbon assimilation, confirming that this compound plays an important role against water stress (Munné-Bosch \& Alegre 2003; Munné-Bosch et al. 2004; Jaleel et al. 2008). By contrast, plastochromanol did not show this kind of correlation, suggesting a less pronounced role than for $\alpha$-tocopherol in the $Q$. pubescens antioxidant response to drought. Moreover, the correlation found between $\alpha$-tocopherol and the xanthophyll cycle is interesting because those compounds are known to have overlapping antioxidant functions as thylakoid membranes protectors (Havaux \& García-Plazaola 2014). The increase of the xanthophyll cycle content concomitantly with the $\Psi_{p d}$ drop confirms this overlap hypothesis. These results suggest that the xanthophyll cycle also plays a key role in the $Q$. pubescens antioxidant system. 
A similar study was performed in 2012 (first year of AD) on isoprene emissions from the same trees (Genard-Zielinski et al. 2017) and highlighted an increase in this compound, whereas we observed a decrease after the $3^{\text {rd }}$ and $4^{\text {th }}$ years of AD. Decreases in isoprene emissions could be problematic for $Q$. pubescens as this compound is known to act as an antioxidant and maintain the stability of thylakoid membranes under oxidative conditions (Velikova et al. 2011). The antioxidant system of $Q$. pubescens could be affected by the isoprene decrease through compensatory mechanisms (Munné-Bosch 2005), but this was apparently not the case since no strong trade-off (indicated by a negative correlation) was detected between isoprene and the major antioxidants (e.g. $\alpha$-tocopherol, xanthophyll cycle antioxidants). By contrast, several positive correlations with these major antioxidants were detected. These results suggest that isoprene could act as an additional antioxidant favoured only in the earlier steps of drought as highlighted in our studies $\left(1^{\text {st }}, 3^{\text {rd }}\right.$ and $4^{\text {th }}$ years $)$. The release of assimilated carbon in isoprene could confirm this hypothesis, as this parameter was higher during the $1^{\text {st }}$ year under AD (Genard-Zielinski et al. 2017) whereas it was the same between treatments after the $3^{\text {rd }}$ and $4^{\text {th }}$ years.

Although phenolic compounds are well known to have a role in photoprotection (Dixon \& Paiva 1995) and are associated with drought resistance (Hernández et al. 2004; Akula \& Ravishankar 2011), they did not respond to drought conditions in our study. Moreover, they did not show compensatory mechanisms or a synergic action with other antioxidants. There is a large variety of phenolic compounds in plants (e.g. flavonols, flavanols, anthocyanins) with many different roles and effects on oxidative stress (Close \& McArthur 2002). For example, it has been demonstrated that the monomeric flavan-3-ols (e.g. catechins), a particular group of flavonoids, had an in vitro antioxidant activity five times higher than tocopherol or ascorbic acid (Blokhina et al. 2003). Thus, it is possible that specific groups or individual phenolic 
compounds rather than the total phenolic content respond to AD (Bernal et al. 2015), which could not be seen with our global analysis.

\section{Growth of $Q$. pubescens could be affected by amplified drought in the long term}

Trees seemed to invest similarly into growth under ND and AD until 2015, at least in terms of leaf biomass production. However, the trunk growth estimated by the increase in DBH started to significantly differ between 2015 and 2016 (between the $4^{\text {th }}$ and the $5^{\text {th }}$ year of AD), indicating that a relatively long period of water stress is needed to observe a significant growth decline in this species. Therefore, the effects of $\mathrm{AD}$ on oak forest growth could be amplified in the coming years. This result could be due to the limiting conditions in terms of precipitation in 2015 or to the recurrent drought (Smith et al. 2009). Moreover, Q. pubescens produced the same quantities of leaves under ND and AD irrespective of the year, which supports this hypothesis. Likewise, Limousin et al. (2012) showed that growth of $Q$. ilex, another major Mediterranean species, was impacted only after 7 years of precipitation restriction in the field.

As a general conclusion, the present work shows that the predicted decrease in rainfall of $30 \%$ by the end of the century associated with climatic change will not strongly affect Downy oak forest ecosystems in the Mediterranean area in the mid-term (after 4 years). Although $Q$. pubescens is a highly drought-resistant species that possesses efficient antioxidant mechanisms (tocopherol, xanthophyll cycle) to cope with oxidative stress, we can anticipate substantial decreases in gas exchange, adjustments of the photosynthetic pigment composition (chlorophylls, carotenoids), impaired growth in the long-term and maybe stronger compensatory mechanisms between antioxidants. 
Even though our study highlights the occurrence of a few metabolic and ecophysiological shifts with water stress recurrence and severity, these investigations could be expanded in further studies by integrating other compounds that are indicators of plant protection against water stress (e.g. enzymatic antioxidants, targeted phenolic compounds, sugars), and by considering longer time scales (probably up to 10 years). This would allow the evaluation of whether the observed shifts in this study become more marked over time and/or the more complete extent of Downy oak resilience. Indeed, as indicated by a European study (KröelDulay et al. 2015) that has investigated the impact of climate change on ecosystems under natural conditions, long periods (over 7 years) of environmental stress may be necessary to observe a negative impact on a given ecosystem, especially in undisturbed ecosystems.

\section{Acknowledgments}

This work was supported by the French National Research Agency (ANR) through the SecPriMe² project (ANR-12-BSV7-0016-01), Europe (FEDER) and ADEME/PACA for PhD funding. We are grateful to FR3098 ECCOREV for the O3HP facilities (https://o3hp.obshp.fr/index.php/fr/). The authors thank the MASSALYA instrumental platform (Aix Marseille Université, lce.univ-amu.fr) for the analysis and measurements of BVOC used in this publication. We are very grateful to J.-P. Orts (IMBE) and I. Reiter (ECCOREV) for their help at the O3HP platform and S. Tourrette (BVME) for some biochemical analyses. We also thank all members of the DFME team from IMBE and, particularly, S. Greff and S. Dupouyet, for their help during measurements and analyses.

\section{Author contribution}

A.S., E.O., M.H. and C.F. designed the research and the experimental design. A.S., B.T.R., E.O., M.H. and C.F. conducted the research. A.S., E.O, M.H., B.K., B.T.R., J.P.M. and C.L. 
collected and analyzed the data. A.S., E.O., H.W., B.T.R., M.H., J.P.M., A.B.M., T.G. and C.F. wrote the manuscript

\section{Conflict of interest}

The authors declare that they have no conflict of interest.

\section{References}

Affek, H.P. \& Yakir, D. (2002). Protection by Isoprene against Singlet Oxygen in Leaves. Plant Physiol., 129, 269 LP-277.

Ahmad, P., Jaleel, C.A., Salem, M.A., Nabi, G. \& Sharma, S. (2010). Roles of enzymatic and nonenzymatic antioxidants in plants during abiotic stress. Crit. Rev. Biotechnol., 30, $161-175$.

Akula, R. \& Ravishankar, G.A. (2011). Influence of abiotic stress signals on secondary metabolites in plants. Plant Signal. Behav., 6, 1720-1731.

Ballottari, M., Dall'Osto, L., Morosinotto, T. \& Bassi, R. (2007). Contrasting behavior of higher plant photosystem I and II antenna systems during acclimation. J. Biol. Chem., 282, 8947-8958.

Bernal, M., Verdaguer, D., Badosa, J., Abadía, A., Llusià, J., Peñuelas, J., et al. (2015). Effects of enhanced UV radiation and water availability on performance, biomass production and photoprotective mechanisms of Laurus nobilis seedlings. Environ. Exp. Bot., 109, 264-275.

Birtic, S., Ksas, B., Genty, B., Mueller, M.J., Triantaphylidès, C. \& Havaux, M. (2011). Using spontaneous photon emission to image lipid oxidation patterns in plant tissues. Plant J., 67, 1103-1115.

Blokhina, O., Virolainen, E. \& Fagerstedt, K. V. (2003). Antioxidants, oxidative damage and oxygen deprivation stress: a review. Ann. Bot., 91, 179-194.

Brilli, F., Barta, C., Fortunati, A., Lerdau, M., Loreto, F. \& Centritto, M. (2007). Response of isoprene emission and carbon metabolism to drought in white poplar (Populus alba) saplings. New Phytol., 175, 244-254.

Brzostek, E.R., Dragoni, D., Schmid, H.P., Rahman, A.F., Sims, D., Wayson, C.A., et al. (2014). Chronic water stress reduces tree growth and the carbon sink of deciduous hardwood forests. Glob. Chang. Biol., 20, 2531-2539.

Von Caemmerer, S. von \& Farquhar, G.D. (1981). Some relationships between the biochemistry of photosynthesis and the gas exchange of leaves. Planta, 153, 376-387.

Cappellin, L., Karl, T., Probst, M., Ismailova, O., Winkler, P.M., Soukoulis, C., et al. (2012). On quantitative determination of volatile organic compound concentrations using proton transfer reaction time-of-flight mass spectrometry. Environ. Sci. Technol., 46, 22832290. 
Chaves, M.M., Flexas, J. \& Pinheiro, C. (2009). Photosynthesis under drought and salt stress: regulation mechanisms from whole plant to cell. Ann. Bot., 103, 551-560.

Chaves, M.M., Maroco, J.P. \& Pereira, J.S. (2003). Understanding plant responses to drought—-from genes to the whole plant. Funct. plant Biol., 30, 239-264.

Close, D.C. \& McArthur, C. (2002). Rethinking the role of many plant phenolics-protection from photodamage not herbivores? Oikos, 99, 166-172.

Close, D.C., McArthur, C., Pietrzykowski, E., Fitzgerald, H. \& Paterson, S. (2004). Evaluating effects of nursery and post-planting nutrient regimes on leaf chemistry and browsing of eucalypt seedlings in plantations. For. Ecol. Manage., 200, 101-112.

Croce, R., Remelli, R., Varotto, C., Breton, J. \& Bassi, R. (1999). The neoxanthin binding site of the major light harvesting complex (LHCII) from higher plants. FEBS Lett., 456, 1-6.

DellaPenna, D. \& Pogson, B.J. (2006). Vitamin synthesis in plants: tocopherols and carotenoids. Annu. Rev. Plant Biol., 57, 711-738.

Demmig-Adams, B. \& Adams, W.W. (1996). The role of xanthophyll cycle carotenoids in the protection of photosynthesis. Trends Plant Sci., 1, 21-26.

Dixon, R.A. \& Paiva, N.L. (1995). Stress-induced phenylpropanoid metabolism. Plant Cell, 7, 1085.

Edge, R., McGarvey, D.J. \& Truscott, T.G. (1997). The carotenoids as anti-oxidants-a review. J. Photochem. Photobiol. B Biol., 41, 189-200.

Ehonen, S., Yarmolinsky, D., Kollist, H. \& Kangasjärvi, J. (2017). Reactive oxygen species, photosynthesis and environment in the regulation of stomata. Antioxidants Redox Signal.

Genard-Zielinski, A.-C., Boissard, C., Fernandez, C., Kalogridis, C., Lathière, J., Gros, V., et al. (2015). Variability of BVOC emissions from a Mediterranean mixed forest in southern France with a focus on Quercus pubescens. Atmos. Chem. Phys., 15, 431-446.

Genard-Zielinski, A.-C., Boissard, C., Ormeño, E., Lathière, J., Guenet, S.B., Gauquelin, T., et al. (2017). Simulating precipitation decline under a Mediterranean deciduous Oak forest: effects on isoprene seasonal emissions and predictions under climatic scenarios.

Genard-Zielinski, A.-C., Ormeño, E., Boissard, C. \& Fernandez, C. (2014). Isoprene emissions from downy oak under water limitation during an entire growing season: what cost for growth? PLoS One, 9, e112418.

Gill, S.S. \& Tuteja, N. (2010). Reactive oxygen species and antioxidant machinery in abiotic stress tolerance in crop plants. Plant Physiol. Biochem., 48, 909-930.

Giorgi, F. \& Lionello, P. (2008). Climate change projections for the Mediterranean region. Glob. Planet. Change, 63, 90-104.

Halliwell, B. (2006). Reactive species and antioxidants. Redox biology is a fundamental theme of aerobic life. Plant Physiol., 141, 312-322.

Havaux, M., Dall'Osto, L. \& Bassi, R. (2007). Zeaxanthin has enhanced antioxidant capacity with respect to all other xanthophylls in Arabidopsis leaves and functions independent of binding to PSII antennae. Plant Physiol., 145, 1506-1520.

Havaux, M. \& García-Plazaola, J.I. (2014). Beyond non-photochemical fluorescence quenching: the overlapping antioxidant functions of zeaxanthin and tocopherols. In: NonPhotochemical Quenching and Energy Dissipation in Plants, Algae and Cyanobacteria. 
Springer, pp. 583-603.

Havaux, M., Triantaphylidès, C. \& Genty, B. (2006). Autoluminescence imaging: a noninvasive tool for mapping oxidative stress. Trends Plant Sci., 11, 480-484.

Hernández, I., Alegre, L. \& Munné-Bosch, S. (2004). Drought-induced changes in flavonoids and other low molecular weight antioxidants in Cistus clusii grown under Mediterranean field conditions. Tree Physiol., 24, 1303-1311.

IPCC. (2013). In: Contribution of working group I to the fifth assessment report of the intergovernmental panel on climate change. Cambridge University Press Cambridge.

Jaleel, C.A., Gopi, R., Manivannan, P., Gomathinayagam, M., Sridharan, R. \& Panneerselvam, R. (2008). Antioxidant potential and indole alkaloid profile variations with water deficits along different parts of two varieties of Catharanthus roseus. Colloids Surfaces B Biointerfaces, 62, 312-318.

Jaleel, C.A., Manivannan, P., Wahid, A., Farooq, M., Al-Juburi, H.J., Somasundaram, R., et al. (2009). Drought stress in plants: a review on morphological characteristics and pigments composition. Int J Agric Biol, 11, 100-105.

Jiang, M. \& Zhang, J. (2002). Water stress- induced abscisic acid accumulation triggers the increased generation of reactive oxygen species and up- regulates the activities of antioxidant enzymes in maize leaves. J. Exp. Bot., 53, 2401-2410.

Jordan, A., Haidacher, S., Hanel, G., Hartungen, E., Märk, L., Seehauser, H., et al. (2009). A high resolution and high sensitivity proton-transfer-reaction time-of-flight mass spectrometer (PTR-TOF-MS). Int. J. Mass Spectrom., 286, 122-128.

Krause, G.H. \& Weis, E. (1991). Chlorophyll fluorescence and photosynthesis: the basics. Annu. Rev. Plant Biol., 42, 313-349.

Kruk, J. \& Karpinski, S. (2006). An HPLC-based method of estimation of the total redox state of plastoquinone in chloroplasts, the size of the photochemically active plastoquinonepool and its redox state in thylakoids of Arabidopsis. Biochim. Biophys. Acta (BBA)Bioenergetics, 1757, 1669-1675.

Kruk, J., Szymańska, R., Cela, J. \& Munne-Bosch, S. (2014). Plastochromanol-8: fifty years of research. Phytochemistry, 108, 9-16.

Kruk, J., Szymańska, R., Nowicka, B. \& Dłużewska, J. (2016). Function of isoprenoid quinones and chromanols during oxidative stress in plants. N. Biotechnol., 33, 636-643.

Kröel-Dulay, G., Ransijn, J., Schmidt, I.K., Beier, C., De Angelis, P., De Dato, G., et al. (2015). Increased sensitivity to climate change in disturbed ecosystems. Nat. Commun., 6,6682 .

Ksas, B., Becuwe, N., Chevalier, A. \& Havaux, M. (2015). Plant tolerance to excess light energy and photooxidative damage relies on plastoquinone biosynthesis. Sci. Rep., 5, srep10919.

Limousin, J.-M., Rambal, S., Ourcival, J.-M., Rodríguez-Calcerrada, J., Pérez-Ramos, I.M., Rodríguez-Cortina, R., et al. (2012). Morphological and phenological shoot plasticity in a Mediterranean evergreen oak facing long-term increased drought. Oecologia, 169, $565-577$.

Lloret, F., Siscart, D. \& Dalmases, C. (2004). Canopy recovery after drought dieback in holm- oak Mediterranean forests of Catalonia (NE Spain). Glob. Chang. Biol., 10, 2092 
2099.

Llusià, J. \& Peñuelas, J. (1998). Changes in terpene content and emission in potted Mediterranean woody plants under severe drought. Can. J. Bot., 76, 1366-1373.

Munne-Bosch, S. (2005). The role of $\alpha$-tocopherol in plant stress tolerance. J. Plant Physiol., $162,743-748$.

Munné-Bosch, S. \& Alegre, L. (2003). Drought-induced changes in the redox state of $\alpha$ tocopherol, ascorbate, and the diterpene carnosic acid in chloroplasts of Labiatae species differing in carnosic acid contents. Plant Physiol., 131, 1816-1825.

Munné-Bosch, S., Penuelas, J., Asensio, D. \& Llusia, J. (2004). Airborne ethylene may alter antioxidant protection and reduce tolerance of holm oak to heat and drought stress. Plant Physiol., 136, 2937-2947.

Nardini, A. \& Pitt, F. (1999). Drought resistance of Quercus pubescens as a function of root hydraulic conductance, xylem embolism and hydraulic architecture. New Phytol., 143, 485-493.

Niinemets, Ü. (2010). Responses of forest trees to single and multiple environmental stresses from seedlings to mature plants: past stress history, stress interactions, tolerance and acclimation. For. Ecol. Manage., 260, 1623-1639.

Noctor, G. \& Foyer, C.H. (1998). Ascorbate and glutathione: keeping active oxygen under control. Annu. Rev. Plant Biol., 49, 249-279.

Park II, Y., Chow, W.S. \& Anderson, J.M. (1997). Antenna size dependency of photoinactivation of photosystem II in light-acclimated pea leaves. Plant Physiol., 115, $151-157$

Polade, S.D., Pierce, D.W., Cayan, D.R., Gershunov, A. \& Dettinger, M.D. (2014). The key role of dry days in changing regional climate and precipitation regimes. Sci. Rep., 4, 4364.

Poyatos, R., Llorens, P., Piñol, J. \& Rubio, C. (2008). Response of Scots pine (Pinus sylvestris L.) and pubescent oak (Quercus pubescens Willd.) to soil and atmospheric water deficits under Mediterranean mountain climate. Ann. For. Sci., 65, 1.

Ramel, F., Birtic, S., Cuiné, S., Triantaphylidès, C., Ravanat, J.-L. \& Havaux, M. (2012). Chemical quenching of singlet oxygen by carotenoids in plants. Plant Physiol., 158, 1267-1278.

Reddy, A.R., Chaitanya, K.V. \& Vivekanandan, M. (2004). Drought-induced responses of photosynthesis and antioxidant metabolism in higher plants. J. Plant Physiol., 161, $1189-1202$.

Santonja, M., Fernandez, C., Gauquelin, T. \& Baldy, V. (2015). Climate change effects on litter decomposition: intensive drought leads to a strong decrease of litter mixture interactions. Plant Soil, 393, 69-82.

Saunier, A., Ormeño, E., Wortham, H., Temime-Roussel, B., Lecareux, C., Boissard, C., et al. (2017). Chronic drought decreases anabolic and catabolic BVOC emissions of Quercus pubescens in a Mediterranean forest. Front. Plant Sci., 8.

Saura-Mas, S., Bonas, A. \& Lloret, F. (2015). Plant community response to drought-induced canopy defoliation in a Mediterranean Quercus ilex forest. Eur. J. For. Res., 134, 261272. 
Smith, M.D., Knapp, A.K. \& Collins, S.L. (2009). A framework for assessing ecosystem dynamics in response to chronic resource alterations induced by global change. Ecology, 90, 3279-3289.

Tholl, D., Boland, W., Hansel, A., Loreto, F., Röse, U.S.R. \& Schnitzler, J. (2006). Practical approaches to plant volatile analysis. Plant J., 45, 540-560.

Velikova, V., Várkonyi, Z., Szabó, M., Maslenkova, L., Nogues, I., Kovács, L., et al. (2011). Increased thermostability of thylakoid membranes in isoprene-emitting leaves probed with three biophysical techniques. Plant Physiol., 157, 905-916.

Vickers, C.E., Gershenzon, J., Lerdau, M.T. \& Loreto, F. (2009). A unified mechanism of action for volatile isoprenoids in plant abiotic stress. Nat. Chem. Biol., 5, 283-291.

Vile, D., Garnier, E., Shipley, B., Laurent, G., Navas, M.-L., Roumet, C., et al. (2005). Specific leaf area and dry matter content estimate thickness in laminar leaves. Ann. Bot., 96, 1129-1136. 
Table 1 Pre-dawn water potential $\left(\Psi_{p d}, \mathrm{MPa}\right)$, midday water potential $\left(\Psi_{m}, \mathrm{MPa}\right)$, net photosynthesis $\left(P n, \mu \mathrm{molCO}_{2} \mathrm{~m}^{-2} \mathrm{~s}^{-1}\right)$, stomatal conductance to water $\left(G w, \mathrm{mmolH}_{2} \mathrm{O} \mathrm{m}^{-2} \mathrm{~s}^{-1}\right)$, water use efficiency $\left(W U E, \mathrm{mmolCO}_{2} \cdot \mathrm{molH}_{2} \mathrm{O}^{-1}\right)$, total chlorophyll (Total Chl, ng mg $\left.{ }_{\mathrm{DM}}{ }^{-1}\right)$, ratio between chlorophyll $a$ and $b(C h l a / C h l ~ b), F v / F m$ and starch content (mg.g $\left.\mathrm{gM}^{-1}\right)$ according to the season and drought in 2014 and 2015 .

Differences between ND and AD were tested with Student tests season by season (mean \pm S.E., $n=5$ ). Letters denote the difference between treatments for each season with $a>b$.

\begin{tabular}{|c|c|c|c|c|c|c|}
\hline \multirow[t]{2}{*}{2014} & \multicolumn{2}{|c|}{ Spring } & \multicolumn{2}{|c|}{ Summer } & \multicolumn{2}{|c|}{ Autumn } \\
\hline & ND & AD & ND & AD & ND & AD \\
\hline$\Psi_{p d}$ & N.A. & N.A. & $-0.70 \pm 0.03 a$ & $-0.90 \pm 0.02 b$ & $-0.53 \pm 0.04 a$ & $-0.75 \pm 0.05 b$ \\
\hline$\Psi_{m}$ & $-2.29 \pm 0.04 a$ & $-2.21 \pm 0.07 \mathrm{a}$ & $-2.52 \pm 0.12 \mathrm{a}$ & $-2.52 \pm 0.14 a$ & N.A. & N.A. \\
\hline$P n$ & $11.0 \pm 1.0 \mathrm{a}$ & $9.1 \pm 1.7 \mathrm{a}$ & $13.6 \pm 2.3 \mathrm{a}$ & $8.7 \pm 1.2 b$ & $16.0 \pm 2.0 \mathrm{a}$ & $11.1 \pm 0.5 b$ \\
\hline$G \boldsymbol{w}$ & $101.7 \pm 18.6 a$ & $56.6 \pm 13.1 b$ & $285.4 \pm 37.7 a$ & $125.9 \pm 17.4 b$ & $328.3 \pm 50.6 a$ & $199.5 \pm 19.3 b$ \\
\hline $\boldsymbol{W U E}$ & $5.88 \pm 0.63 b$ & $9.00 \pm 0.34 \mathrm{a}$ & $3.57 \pm 0.67$ & $3.55 \pm 0.44$ & $5.61 \pm 1.30$ & $4.37 \pm 0.49$ \\
\hline Total Chl & $3986 \pm 229 a$ & $3895 \pm 145 a$ & $4086 \pm 84 a$ & $4140 \pm 116 a$ & $3255 \pm 150 \mathrm{a}$ & $2954 \pm 200 \mathrm{a}$ \\
\hline Chla/Chlb & $4.42 \pm 0.03 a$ & $4.35 \pm 0.03 a$ & $4.50 \pm 0.05 a$ & $4.49 \pm 0.07 \mathrm{a}$ & $4.80 \pm 0.06 \mathrm{a}$ & $4.81 \pm 0.17 \mathrm{a}$ \\
\hline$F v / F m$ & $0.76 \pm 0.01 \mathrm{a}$ & $0.77 \pm 0.02 \mathrm{a}$ & $0.84 \pm 0.01 \mathrm{a}$ & $0.83 \pm 0.003 a$ & $0.84 \pm 0.01 \mathrm{a}$ & $0.85 \pm 0.01 \mathrm{a}$ \\
\hline Starch content & $49.0 \pm 6.2 \mathrm{a}$ & $46.9 \pm 8.0 \mathrm{a}$ & $20.2 \pm 5.7 \mathrm{a}$ & $27.6 \pm 4.1 \mathrm{a}$ & $24.7 \pm 2.2 \mathrm{a}$ & $25.8 \pm 2.3 \mathrm{a}$ \\
\hline \multirow[t]{2}{*}{2015} & \multicolumn{2}{|c|}{ Spring } & \multicolumn{2}{|c|}{ Summer } & \multicolumn{2}{|c|}{ Autumn } \\
\hline & ND & AD & ND & AD & ND & AD \\
\hline$\Psi_{p d}$ & $-0.73 \pm 0.06 a$ & $-0.86 \pm 0.02 a$ & $-2.41 \pm 0.11 \mathrm{a}$ & $-2.74 \pm 0.09 b$ & $-1.13 \pm 0.06 a$ & $-2.00 \pm 0.24 b$ \\
\hline$\Psi_{m}$ & $-2.30 \pm 0.03 a$ & $-2.27 \pm 0.07 \mathrm{a}$ & $-3.46 \pm 0.03 a$ & $-3.59 \pm 0.05 a$ & $-2.63 \pm 0.11 \mathrm{a}$ & $-3.33 \pm 0.09 b$ \\
\hline$P n$ & $9.6 \pm 1.5 \mathrm{a}$ & $10.0 \pm 0.6 \mathrm{a}$ & $3.2 \pm 0.8 \mathrm{a}$ & $1.3 \pm 0.6 b$ & $19.1 \pm 0.6 \mathrm{a}$ & $2.8 \pm 0.9 b$ \\
\hline$G w$ & $81.4 \pm 22.5 b$ & $156.1 \pm 29.0 \mathrm{a}$ & $80.2 \pm 24.4 \mathrm{a}$ & $3.8 \pm 2.2 b$ & $255.2 \pm 54.8 \mathrm{a}$ & $13.8 \pm 8.3 b$ \\
\hline $\boldsymbol{W U E}$ & $8.76 \pm 2.05$ & $4.54 \pm 0.33$ & $2.15 \pm 0.30 b$ & $25.00 \pm 22.32 \mathrm{a}$ & $6.47 \pm 0.68$ & $13.45 \pm 5.39$ \\
\hline Total Chl & $4296 \pm 196 a$ & $4524 \pm 318 \mathrm{a}$ & $3341 \pm 65 a$ & $3072 \pm 170 \mathrm{a}$ & $3137 \pm 76 a$ & $2709 \pm 204 b$ \\
\hline Chla/Chlb & $3.63 \pm 0.07 b$ & $4.06 \pm 0.06 \mathrm{a}$ & $4.26 \pm 0.09 a$ & $4.49 \pm 0.13 \mathrm{a}$ & $4.14 \pm 0.04 b$ & $4.84 \pm 0.16 \mathrm{a}$ \\
\hline$F v / F m$ & $0.77 \pm 0.003 \mathrm{a}$ & $0.78 \pm 0.01 \mathrm{a}$ & $0.84 \pm 0.02 \mathrm{a}$ & $0.83 \pm 0.01 \mathrm{a}$ & $0.83 \pm 0.01 \mathrm{a}$ & $0.80 \pm 0.02 \mathrm{a}$ \\
\hline Starch content & $45.9 \pm 5.7 \mathrm{a}$ & $33.8 \pm 4.5 \mathrm{a}$ & $24.3 \pm 2.4 \mathrm{a}$ & $26.9 \pm 6.5 \mathrm{a}$ & $39.6 \pm 4.9 \mathrm{a}$ & $37.0 \pm 4.1 \mathrm{a}$ \\
\hline
\end{tabular}

N.A.: not available 
Table 2 Estimated leaf biomass production $\left(\mathrm{g} \mathrm{m}^{-2}\right)$ in 2014, 2015 and 2016, the increase of DBH (Increase ${ }_{\text {DBH }}$, in cm.yr ${ }^{-1}$, difference between DBH in 2015 and 2016) and the leaf mass per area (LMA, $\mathrm{g} \mathrm{m}^{-2}$ ) for autumn 2014 and 2015. These 3 traits were tested with student tests (mean \pm S.E., $n=8$ for leaf biomass; for increase ${ }_{\mathrm{DBH}}, \mathrm{n}=146$ in ND plot and $\mathrm{n}=52$ in AD plot; for LMA, $n=5$ ). Letters denote the difference between treatments for each season with $a>b$.

\begin{tabular}{|c|c|c|c|c|c|c|}
\hline & \multicolumn{2}{|c|}{2014} & \multicolumn{2}{|c|}{2015} & \multicolumn{2}{|c|}{2016} \\
\hline & ND & $\mathrm{AD}$ & ND & $\mathrm{AD}$ & ND & $\mathrm{AD}$ \\
\hline $\begin{array}{l}\text { Leaf biomass } \\
\text { production }\end{array}$ & $137.8 \pm 18.2 \mathrm{a}$ & $169.2 \pm 18.8 \mathrm{a}$ & $143.0 \pm 15.6 a$ & $158.0 \pm 13.5 \mathrm{a}$ & $178.4 \pm 21.4 \mathrm{a}$ & $194.2 \pm 25.1 \mathrm{a}$ \\
\hline Increase $_{D B H}$ & N.A & N.A. & N.A. & N.A & $0.13 \pm 0.01 \mathrm{a}$ & $0.08 \pm 0.02 b$ \\
\hline$L M A$ & $136.7 \pm 5.9 a$ & $134.7 \pm 5.0 \mathrm{a}$ & $141.1 \pm 8.5 \mathrm{a}$ & $133.4 \pm 5.3 \mathrm{a}$ & N.A. & N.A. \\
\hline
\end{tabular}


Table 3: Spearman's coefficients of correlations between antioxidants [ $\alpha$-tocopherol, plastochromanol, lutein, $\beta$-carotene, neoxanthin and xanthophyll cycle (violaxanthin+zeaxanthin+antheraxanthin, called V+Z+A)], isoprene, phenolic compounds, and physiological parameters [predawn water potential in absolute value $\left(\Psi_{p d}\right)$ and net photosynthesis $\left.(P n)\right]$ in summer with data from the different years and drought treatments merged together. Coefficients are marked with bold font when correlations were significant at the at least $95 \%$ of confidence interval ( $\mathrm{n}=20, *$ : $0.01<\mathrm{P}<0.05, * *: 0.001<\mathrm{P}<0.01, * * *: \mathrm{P}<0.001)$.

\begin{tabular}{|c|c|c|c|c|c|c|c|c|c|}
\hline Summer & $\alpha$-tocopherol & plastochromanol & lutein & $\beta$-carotene & neoxanthin & $V+Z+A$ & Isoprene & phenolic c. & $\boldsymbol{\Psi}_{p d}$ \\
\hline plastochromanol & 0.27 & & & & & & & & \\
\hline lutein & $-0.45 *$ & 0.37 & & & & & & & \\
\hline$\beta$-carotene & $-0.63 * *$ & 0.28 & $0.87 * * *$ & & & & & & \\
\hline neoxanthin & $-0.69 * *$ & 0.19 & $0.89 * * *$ & $0.89 * * *$ & & & & & \\
\hline$V+Z+A$ & $0.59 * *$ & $0.52 *$ & -0.05 & 0.10 & -0.14 & & & & \\
\hline isoprene & 0.24 & -0.05 & 0.19 & 0.05 & 0.18 & -0.07 & & & \\
\hline phenolic $c$. & -0.15 & 0.24 & 0.20 & 0.18 & 0.28 & -0.13 & $0.57 *$ & & \\
\hline$\Psi_{p d}$ & $0.83 * * *$ & 0.34 & -0.34 & $-0.46^{*}$ & $-0.57 *$ & $0.63 * *$ & -0.25 & -0.33 & \\
\hline$P n$ & $-0.77 * * *$ & -0.11 & 0.29 & 0.32 & 0.55 & $-0.50 *$ & 0.18 & 0.37 & $-0.82 * * *$ \\
\hline
\end{tabular}


Figure 1 Oak Observatory at Observatoire de Haute-Provence $\left(\mathrm{O}_{3} \mathrm{HP}\right)$. (a) Experimental site with the exclusion device opened, (b) experimental site with the exclusion device closed (to exclude rain) and (c) scheme of $\mathrm{O}_{3} \mathrm{HP}$ with the tree repartition in the field.

Figure 2 Ombrothermic diagram for ND and AD between 2012 and 2015. Bars represent mean monthly precipitation $(\mathrm{P}, \mathrm{mm})$ and curves represent mean monthly temperature $\left(\mathrm{T},{ }^{\circ} \mathrm{C}\right)$ with $\mathrm{P}=2 \mathrm{~T}$. Horizontal arrows indicate drought periods (which occur when the temperature curves are above the precipitations bars), vertical arrows indicate field campaigns and dotted arrows at the bottom of the $\mathrm{x}$ axis represent the exclusion period (i.e. when rain shelters were deployed).

Figure 3 Cumulative precipitation for ND and AD plots in 2014 and 2015. The dotted line represents the annual mean precipitation calculated for the period 1967-2000 (Santonja et al. 2015), which is equal to $830 \mathrm{~mm}$.

Figure 4 Autoluminescence imaging of lipid peroxidation in Downy oak leaves. (a) Control experiment showing the increase in autoluminescence upon exposure of leaves for $22 \mathrm{~h}$ to photooxidative stress conditions at low leaf temperature $\left(\mathrm{HL}, 14^{\circ} \mathrm{C}\right)$ induced by high PFD $\left(1800 \mu \mathrm{mol} . \mathrm{m}^{-2} . \mathrm{s}^{-1}\right)$. The color scale indicates signal intensity from 0 (black) to saturation (white). (b) Autoluminescence imaging of leaves taken from trees under ND and AD conditions in July 2014 and July 2015. Left: picture of the leaves; right: autoluminescence image. (c) Quantification of the luminescence signals. The color scale in panel (a) indicates signal intensity ranging from 0 (black) to saturation (white).

Figure 5 Leaf concentrations of the tocochromanol-like antioxidants: $\alpha$-tocopherol (a, b) and plastochromanol (c, d) in 2014 and 2015, respectively, according to the season and the drought treatment. Differences between seasons were tested with post-hoc Tukey tests and are indicated with different letters $(\mathrm{a}>\mathrm{b}>\mathrm{c})$. Differences between drought treatments were tested with Student tests, with asterisks indicating significant differences between AD and ND. *: $P<0.05$ and $* *: P<0.01$. Values are mean \pm S.E., $\mathrm{n}=7$.

Figure 6 Leaf concentrations of the antioxidant pigments lutein $(\mathbf{a}, \mathbf{b}), \beta$-carotene $(\mathbf{c}, \mathbf{d})$, neoxanthin (e, f) and xanthophyll cycle (violaxanthin+zeaxanthin+antheraxanthin, $\mathbf{g}, \mathbf{h})$ in 2014 and 2015, according to the season and the drought treatment. Differences between 
seasons are tested with post-hoc Tukey tests and are indicated with different letters $(\mathrm{a}>\mathrm{b}>$ c). Differences between drought treatments were tested with Student tests, with asterisks indicating significant differences between AD and ND. **: $0.001<P<0.01$ and ***: $P<$ 0.001. Values are mean \pm S.E., $n=7$.

Figure 7 Emission rates of isoprene (ER isoprene, $\mu \mathrm{gC} \cdot \mathrm{g}_{\mathrm{DM}}{ }^{-1} \cdot \mathrm{h}^{-1}$ ) according to the drought treatments and the season in 2014 and 2015. Differences between drought treatments were tested with Student tests, with asterisks indicating significant differences between AD and ND. Differences between seasons were tested with post-hoc Tukey tests and are indicated with different letters $(\mathrm{a}>\mathrm{b}>\mathrm{c}) . *: 0.01<P<0.05$. Values are means \pm S.E., $\mathrm{n}=5$.

Figure 8 Concentration of total phenolic compounds $\left(\mathrm{mg}_{\text {eq. gallic acid. }} \mathrm{g}^{-1}\right)$ according to the drought treatments and the season in 2014 and 2015. Differences between drought treatments were tested with Student tests, with the absence of asterisks indicating that no significant differences occurred between $\mathrm{AD}$ and ND. Differences between seasons were tested with post-hoc Tukey tests with the absence of different letters indicating that no significant differences occurred. Values are mean \pm S.E., $n=5$.

Figure 9 Principal component analyses (PCA) based on standardized antioxidant concentrations ( $\alpha$-tocopherol, plastochromanol, lutein, $\beta$-carotene, neoxanthin, violaxanthin+zeaxanthin+antheraxanthin, isoprene and phenolic compounds) according to the drought treatment and years, by season. 

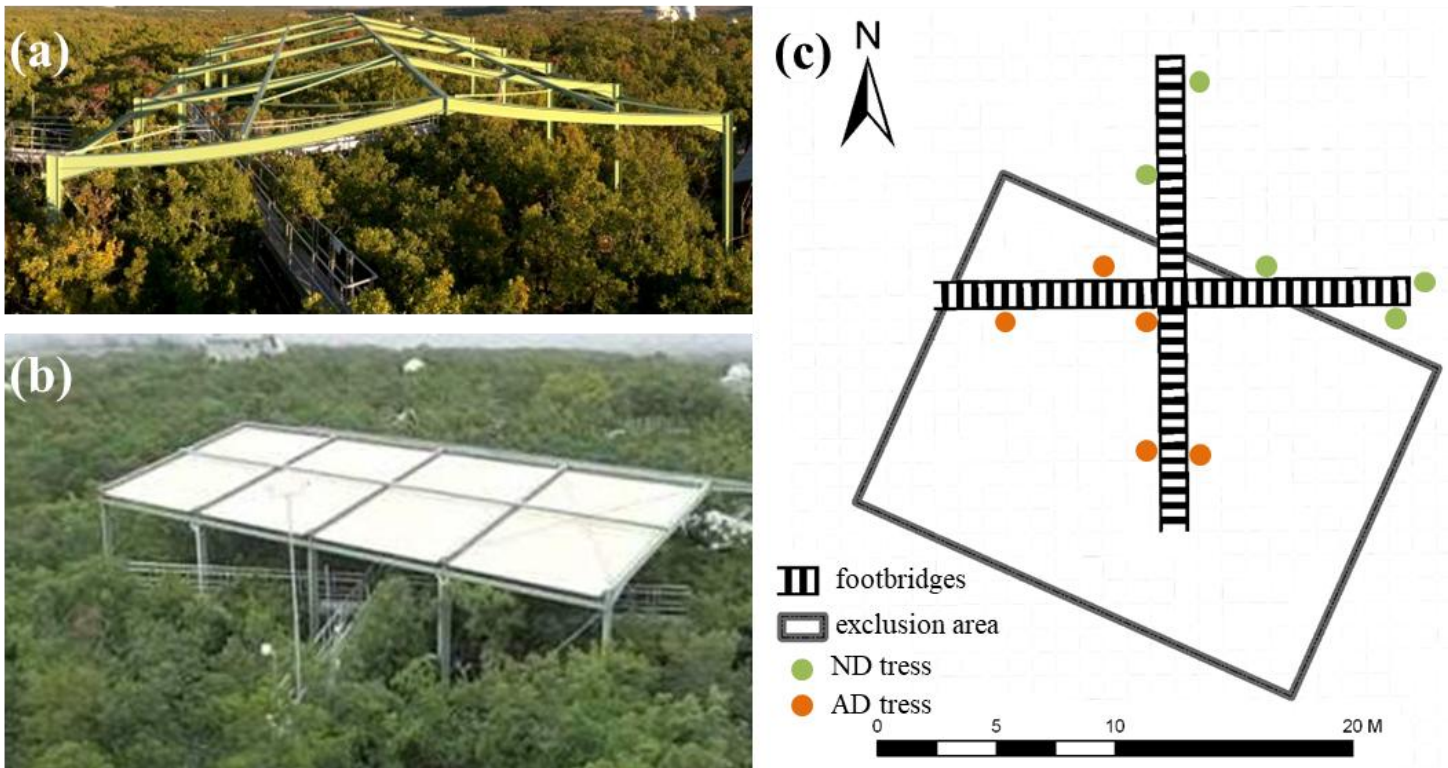

Figure 1 

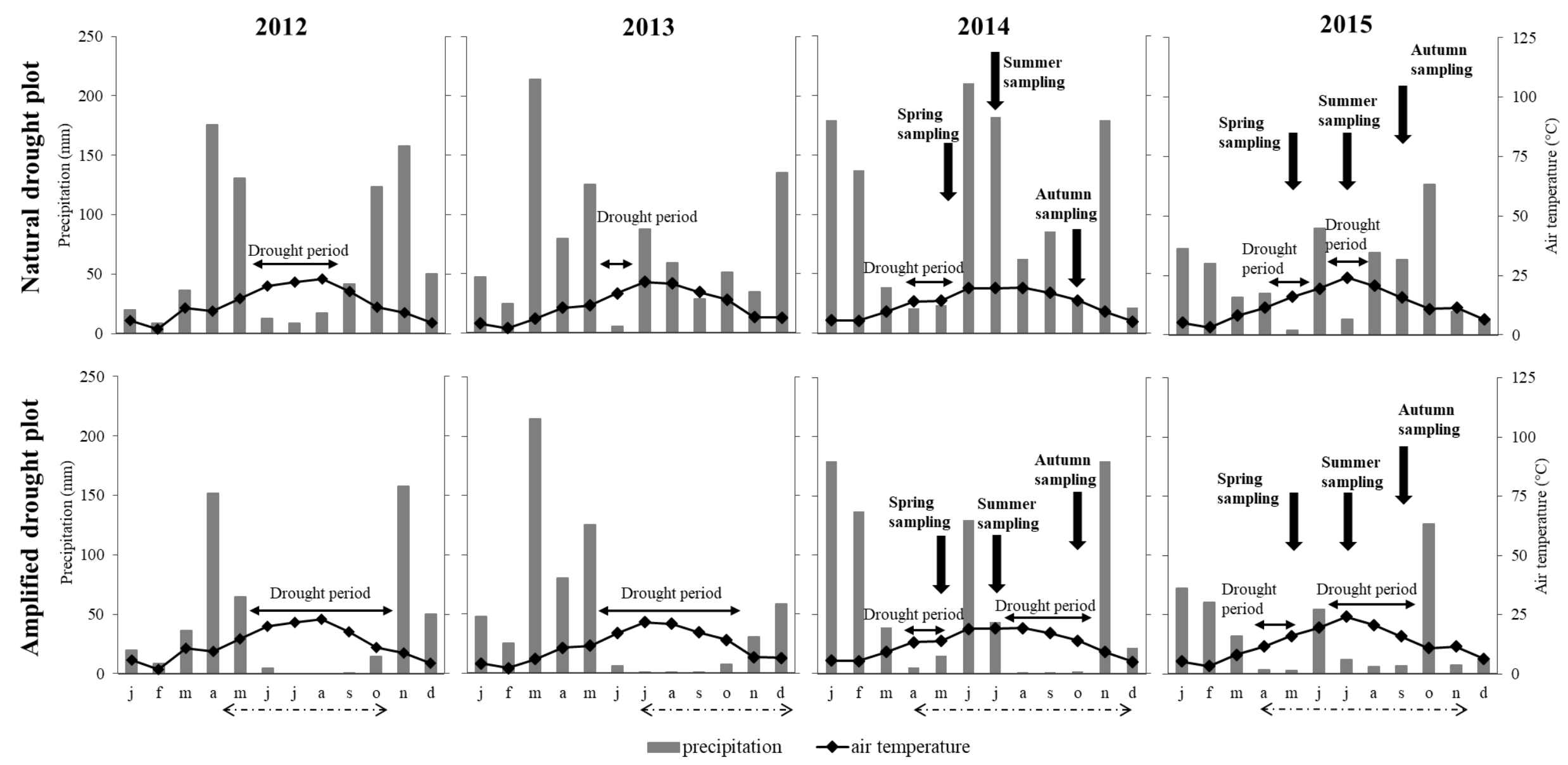

Figure 2 


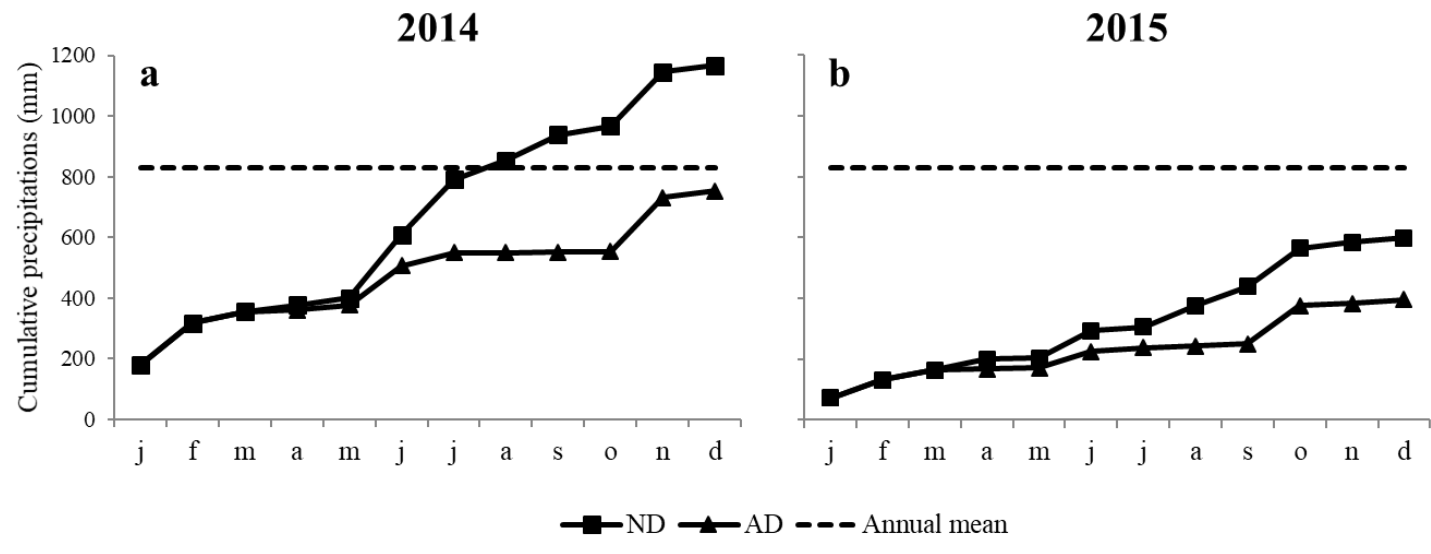

Figure 3 
(a)

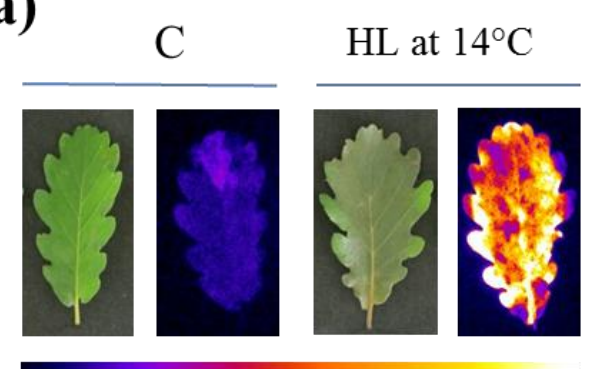

(b)

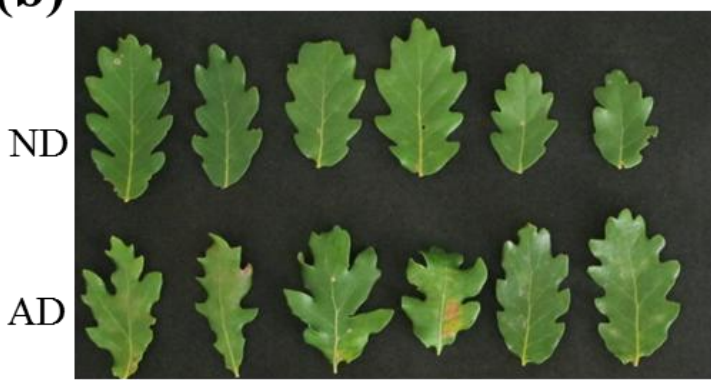

July 2015

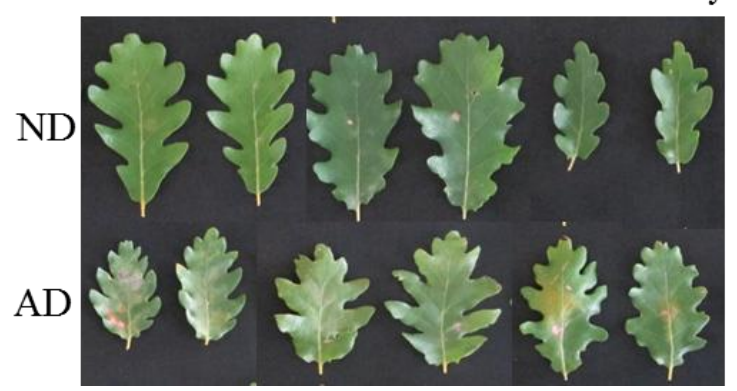

(c) $)_{80}$

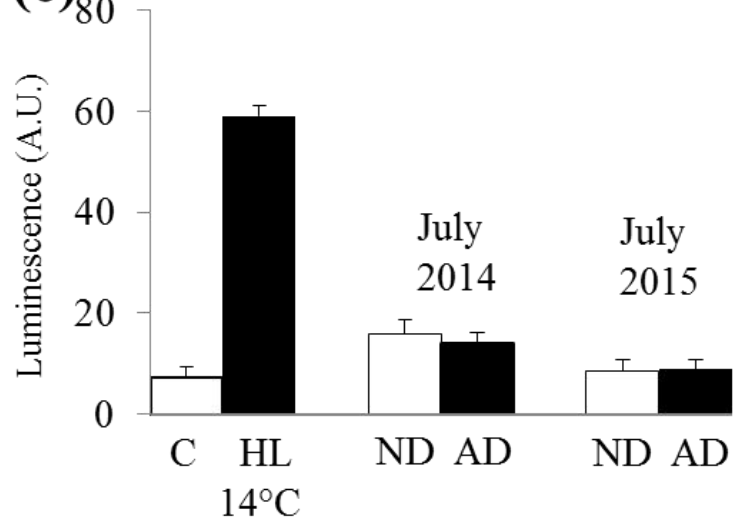

July 2014
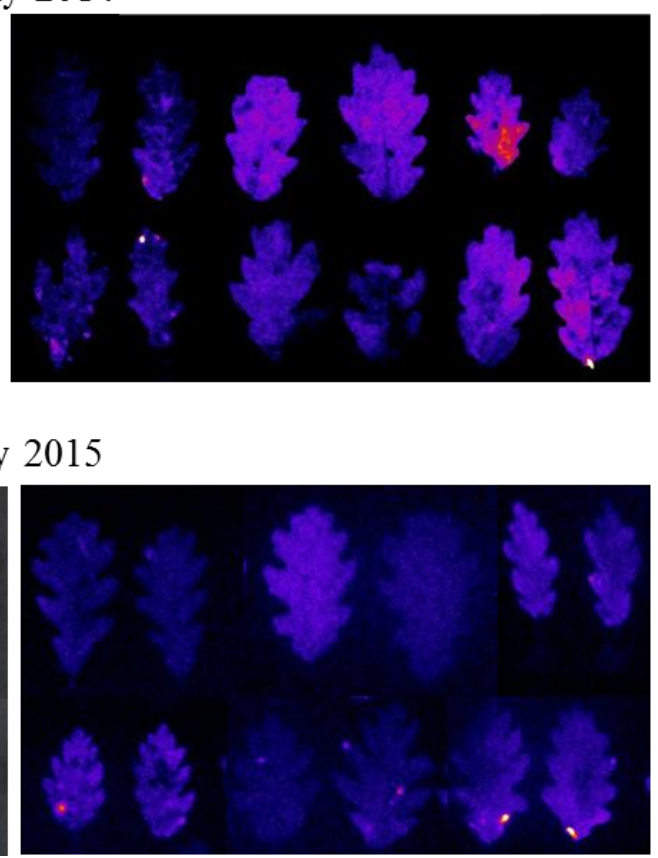

Figure 4 

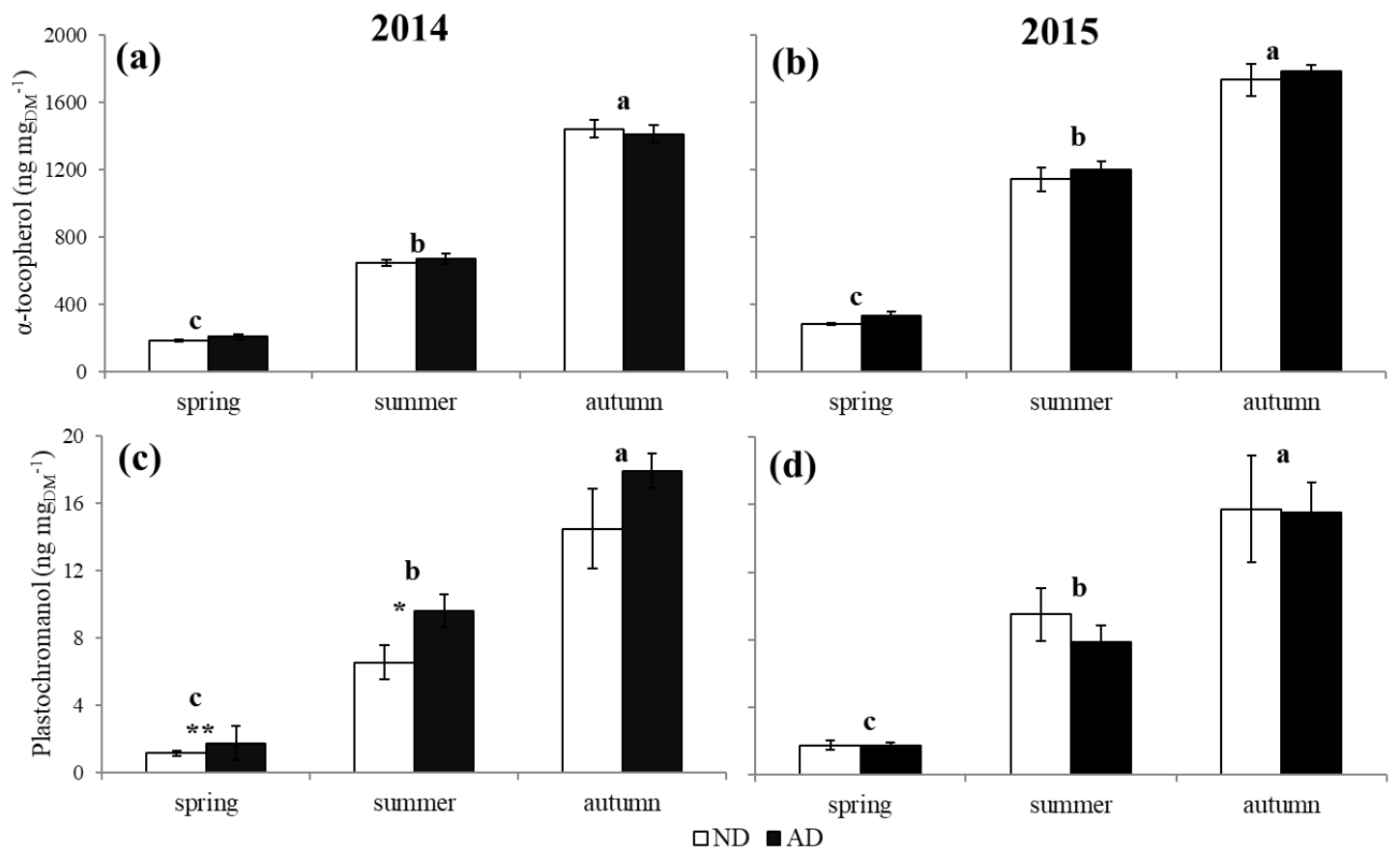

Figure 5 

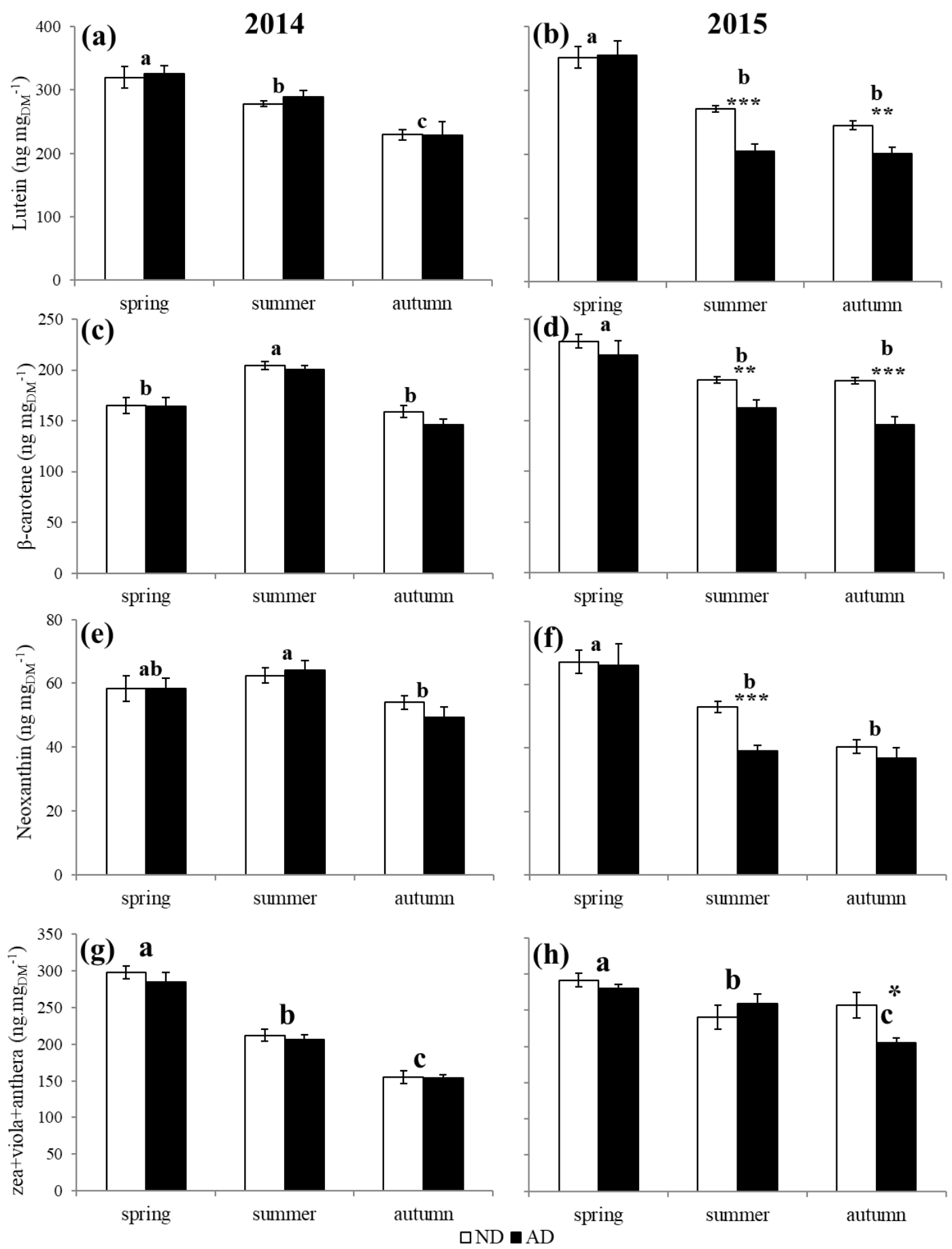

Figure 6 


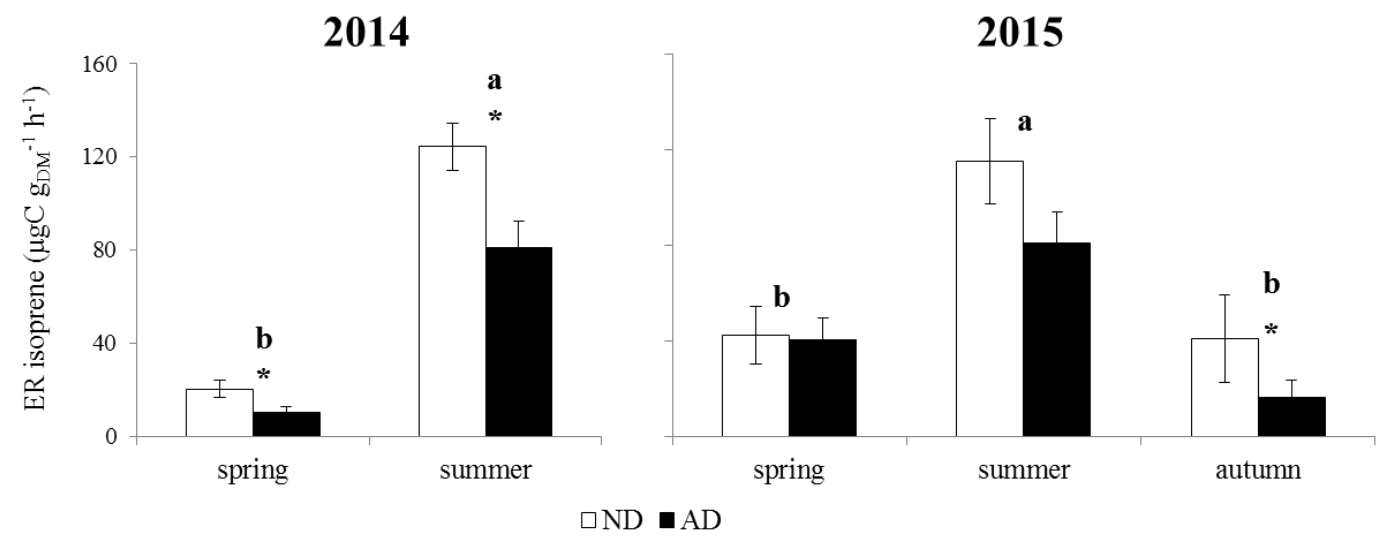

Figure 7 


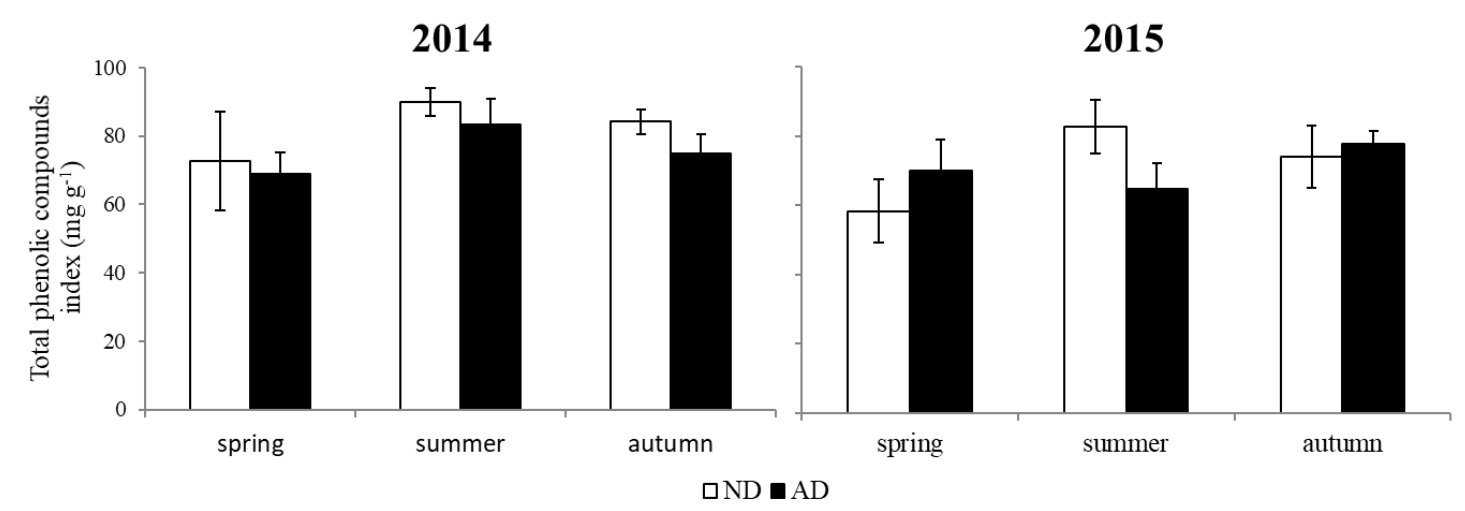

Figure 8 


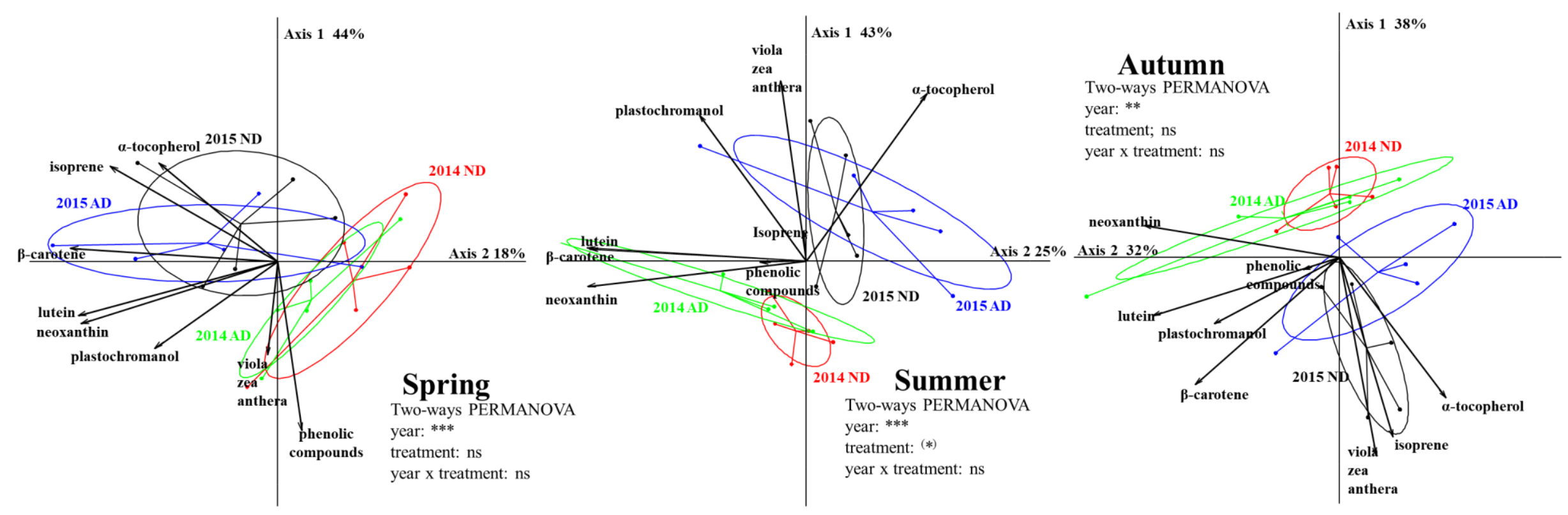

Figure 9 